\title{
Multicomponent diffusion modeling in clay systems with application to the dif- fusion of tritium, iodide and sodium in Opalinus Clay
}

\author{
C. Anthony J. Appelo* and Paul Wersin \\ Hydrochemical Consultant, Valeriusstraat 11, $1071 \mathrm{MB}$ Amsterdam, The Netherlands \\ ( ${ }^{*}$ corresponding author phone: +31-(20)-671-636-6; fax: +30-(20)-671-636-6; e-mail: \\ appt@xs4all.nl) \\ and \\ Nagra, Hardstrasse 73, CH-5430 Wettingen, Switzerland
}

\section{Supporting Information for the paper in Environ. Sci. Technol.}

19 April, 2007

\section{Contents:}

-- the implementation of multicomponent diffusion (MCD) in PHREEQC

-- the new input options and structure of input files for calculating MCD with PHREEQC

-- a test example that compares multicomponent diffusion of $\mathrm{CaCl}_{2}$ and $\mathrm{NaCl}$

-- an example comparing concentrations in the DDL by integration and Donnan approximation

-- iodide profiles in the clay-rock that show the accessible porosity to be half of the total in Opalinus Clay

-- PHREEQC input files for test examples and Figures 3a-d and Figure 4 in the paper

(27 pages, 5 figures, 1 table) 


\section{Implementation}

The multicomponent diffusion equation,

$$
J_{i}=-D_{w, i}\left(\frac{\partial \ln \left(\gamma_{i}\right)}{\partial \ln \left(c_{i}\right)}+1\right) \frac{\partial c_{i}}{\partial x}+D_{w, i} z_{i} c_{i} \frac{\sum_{j=1}^{n} D_{w, j} z_{j}\left(\frac{\partial \ln \left(\gamma_{j}\right)}{\partial \ln \left(c_{j}\right)}+1\right) \frac{\partial c_{j}}{\partial x}}{\sum_{j=1}^{n} D_{w, j} z_{j}^{2} c_{j}}
$$

was programmed in PHREEQC, calculating the fluxes for all the species individually both in the free pore and the DDL, and then summing up for the interface between two model cells. The diffusion coefficients are the tracer diffusion coefficients in water for individual species $\left(D_{w}\right.$ in $\left.\mathrm{m}^{2} / \mathrm{s}\right)$, corrected for temperature and viscosity (Atkins and dePaula, 2002), and recalculated to porewater diffusion coefficients $\left(D_{p}\right)$ with the formula:

$$
D_{p}=D_{w} \varepsilon_{\mathrm{w}}{ }^{n}
$$

where $\varepsilon_{\mathrm{W}}$ is the water filled porosity $(-)$, and $n$ is an empirical exponent $(\approx 0.9-1.2$, Grathwohl, 1998; Appelo and Postma, 2005). The fluxes found with Equation (12) are 1) multiplied with the interfacial surface $\varepsilon_{\mathrm{w}} A\left(\mathrm{~m}^{2}\right)$ of 2 cells, taking the smallest $\varepsilon_{\mathrm{w}}$ in case the values are different for the 2 cells, 2) multiplied with the maximal permitted timestep for the solute with the highest diffusion coefficient (usually $\mathrm{H}^{+}$), and 3) divided by the volume of the cell to obtain the concentration changes (mol/L) of all the individual solute species (ions, complexes) due to diffusion over the interface. The concentration changes of solute species are summed up as concentration changes of master species (components), which are speciated again by PHREEQC after each diffusive timestep.

\section{New input options and structure of input files}

The tracer diffusion coefficient in water at $25^{\circ} \mathrm{C}$ can be defined with identifier '-dw' under keyword SOLUTION_SPECIES:

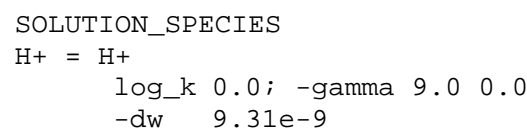

A database (phreeqd.dat) with diffusion coefficients for individual solutes was constructed (Robinson and Stokes, 1959; Pikal, 1971; Jähne et al., 1987; Lasaga, 1998).

A new identifier '-multi_d' was added to keyword TRANSPORT:

-multi_d true $1 e-90.30 .01 .0$ \# [true/false] [default_Dw in $\mathrm{m} 2 / \mathrm{s}$ ] [porosity] [porosity
limit] [n]

The [default Dw] is the default tracer diffusion coefficient for species for which '-dw' has not been defined. The [porosity] is used, initially uniformly for all the cells in the model, to calculate the porewater diffusion coefficient and the effective surface area for diffusion the porosity can be changed in a USER_keyword, see below). If the porosity, by precipitation of solids or other reactions, falls below [porosity limit], diffusion stops for that cell. The exponent $[\mathrm{n}]$ is used for calculating the pore water diffusion coefficient according to Equation (S1). In the example, the porewater diffusion coefficient becomes $D_{p}=0.3 \times 10^{-9}=0.3 \times 10^{-9} \mathrm{~m}^{2} / \mathrm{s}$.

For mobile cells, PHREEQC can be run as usual, setting '-multi_d' true. For immobile cells, mixing factors among cells must be defined using keyword MIX, according to Equation (128) in the PHREEQC-2 manual: 


$$
\operatorname{mixf}_{i j}=\frac{D_{p} \Delta t \varepsilon_{w} A_{i j}}{h_{i j} V_{i}} f_{b c}
$$

where $\Delta t$ is the timestep (s), $A_{i j}$ is the shared surface area among cells $i$ and $j\left(\mathrm{~m}^{2}\right), h_{i j}$ is the distance between midpoints of the cells $(\mathrm{m}), V_{i}$ is the water volume in cell $i$ for which the concentration change is calculated $\left(\mathrm{m}^{3}\right)$, and $f_{b c}$ is a correction factor that equals 2 for constant concentration boundary cells and is 1 otherwise.

One and the same volume $V_{i}=0.001 \mathrm{~m}^{3}$ must be used in Equation (S2) for all the immobile cells, but the amount of water in the SOLUTION's may be adapted to mimic volume variations among the cells. The pore water diffusion coefficient $D_{p}$ in Equation (S2) must be tractable for PHREEQC from Equation (S1), $D_{p}=D_{w} \varepsilon_{w}{ }^{n}$, and the porosity $\varepsilon_{w}$, the exponent $n$ and the tracer diffusion coefficient $D_{w}$ (used for calculating mixing factors) must be entered after identifier 'multi_d' in the input file. PHREEQC compares $D_{w, i}$ of solute species $i$ with the default value and increases or decreases the mixing factor accordingly (while taking care that, overall, the zero charge flux is maintained). An interface should be defined only once since the concentration changes are calculated for both the cells on the interface (this contrasts with the default option, where mixing factors must be defined separately for each cell). If PHREEQC warns that negative concentrations are encountered in MCD, the timestep used for calculating the mixing factor must be decreased (and the number of shifts must be increased in proportion).

The following example input file calculates about 30 years diffusion of a $\mathrm{NaCl}$ solution, comparing multicomponent diffusion with the standard 'mixrun' option, while both calculations employ the same effective diffusion coefficient. Note how SOLUTIONs and MIXs are defined differently with MCD and mixrun. The calculated results are the same, except for the effect of the activity correction on diffusion that is applied in MCD.

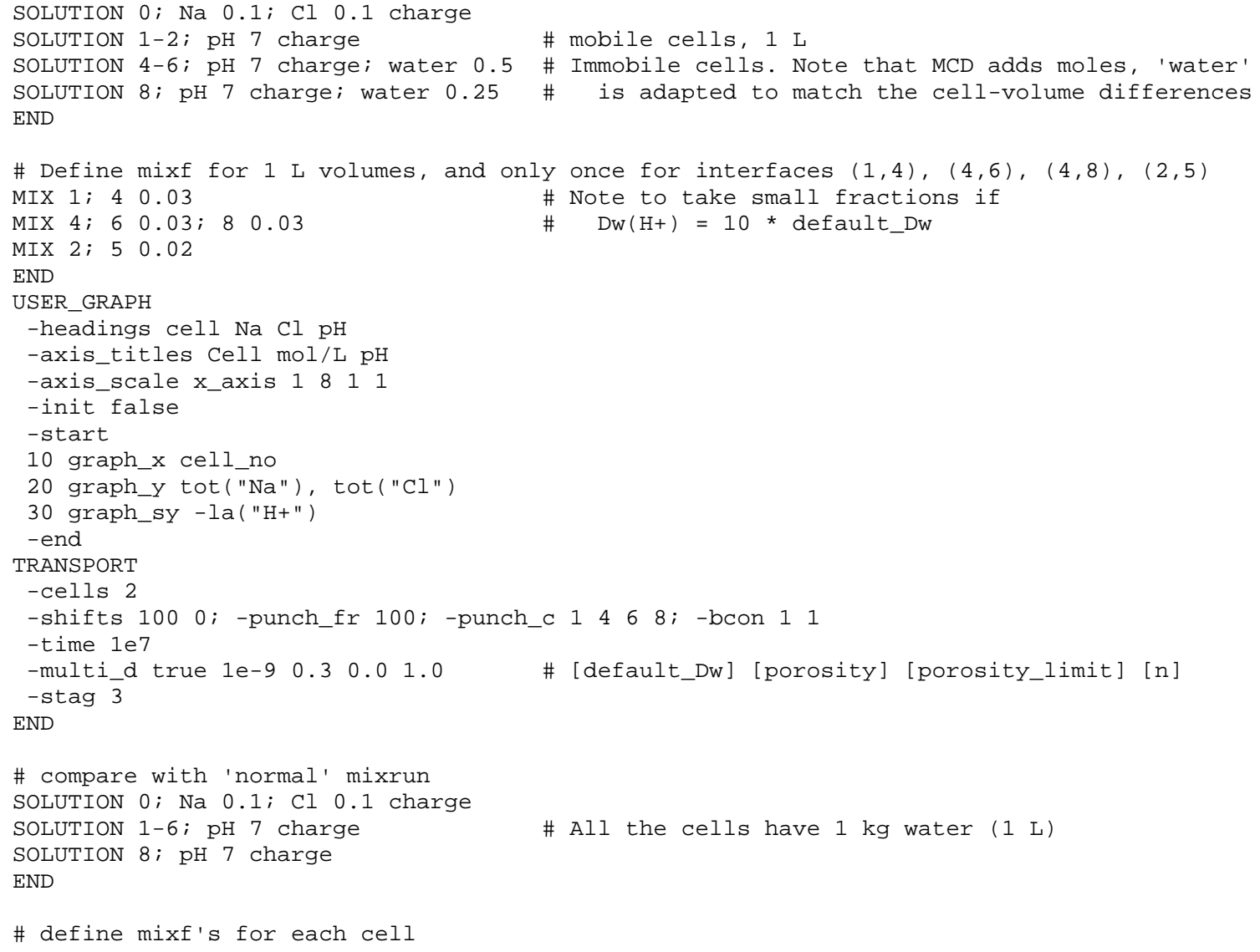




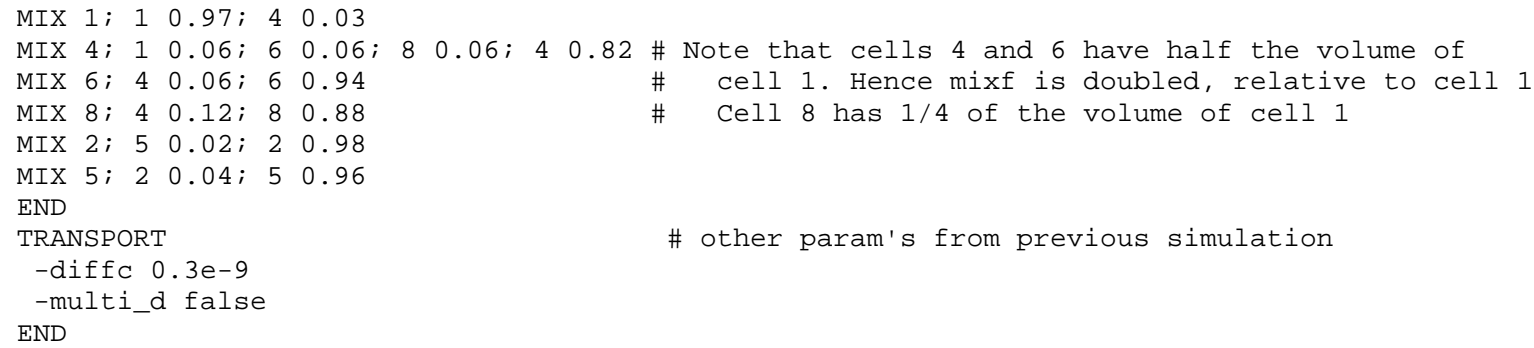

Two new special BASIC functions were added:

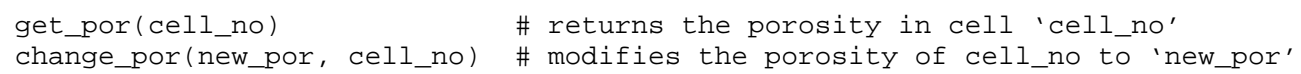

Keyword SURFACE was extended with an identifier for Donnan calculations:

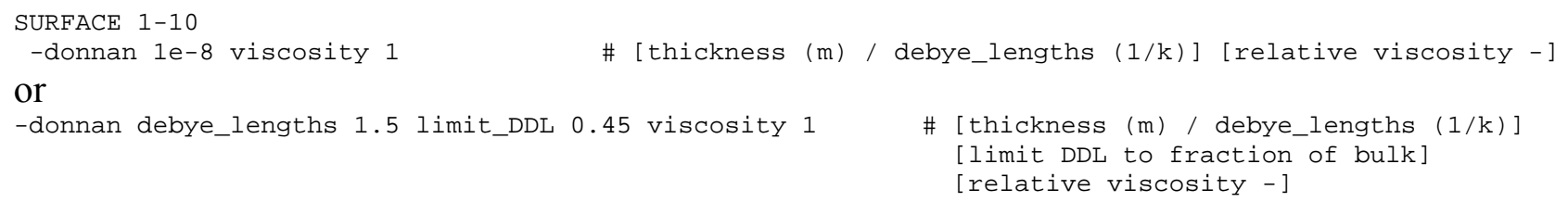

Option '-only_counter_ions' can be used with '-donnan'. However, when used in conjunction with the Donnan option, all the co-ions (with the same sign of charge as the surface) will be excluded from the DDL, and they will be given a concentration of (near) zero in the DDL $\left(c_{i, \mathrm{DDL}}=0\right)$. This contrasts with the combination of option '-diffuse_layer' and '-only_counter_ions', in which the coions are assigned the concentrations of the free solution $\left(c_{i, \mathrm{DDL}}=c_{i}\right)$.

The thickness of the diffuse double layer (DDL) can be fixed (first example line) or vary with ionic strength in number of debye lengths $\left(\kappa^{-1}\right)$ (second example line). The Debye length is defined as:

$$
\kappa^{-1}=\sqrt{\frac{\left(\varepsilon_{0} \varepsilon_{w}\right) \mathrm{R} T}{2 \mathrm{~F}^{2} I}}
$$

where $\left(\varepsilon_{0} \varepsilon_{\mathrm{w}}\right)$ is the dielectric constant of water, and $I$ is the ionic strength. The number $(d)$ of Debye lengths can be defined in the input file, and PHREEQC calculates the thickness $r_{d}=d \kappa^{-1}$ as a function of the ionic strength. The maximal amount of DDL water can be fixed to a fraction of total water by 'limit_DDL' (default limit_DDL $=0.8$ ). The viscosity of the DDL can be set relative to the viscosity of water $\left(\eta\right.$ DDL $\left./ \eta_{\mathrm{H}_{2} \mathrm{O}}\right)$.

With the variable thickness option, a pore radius is calculated from the amount of water in the solution with which the initial surface is equilibrated (initial_surface) or from the total amount of water (the total of free solution and DDL water). In the first case, $r$ is solved from the equation:

$$
V_{a q}=\pi\left(r-r_{d}\right)^{2}(L \times \theta)
$$

where $V_{a q}$ is the volume of the solution (assuming $1 \mathrm{~kg}$ equals $1 \mathrm{dm}^{3}$ ), $L$ is the cell-length $(\mathrm{m})$ and $\theta$ is the tortuosity (-). The product of the latter 2 is implicitly available in the surface area $A_{s}$ that is defined with each SURFACE in the input file, or:

$$
A_{s}=2 \pi r(L \times \theta)
$$

The volume water associated with the surface is now given by: 


$$
V_{\text {surf }}=\frac{r^{2}-\left(r-r_{d}\right)^{2}}{\left(r-r_{d}\right)^{2}} V_{a q}
$$

and the total volume of water is $V_{\text {tot }}=V_{a q}+V_{\text {surf }}$.

In the second case, $r$ is solved simply from

$$
V_{\text {tot }}=\pi r^{2}(L \times \theta)
$$

or

$$
r=2 V_{t o t} / A_{s}
$$

If, in any of the above cases, $V_{\text {surf }}>$ limit_DDL $\times V_{\text {tot }}$, then $r_{d}$ is adapted to give $V_{\text {surf }}=$ limit_DDL $\times V_{\text {tot }}$.

It should be noted that PHREEQC's surface complexation model employs a potential term for a planar surface. Thus, the pore sizes written in the output file are only approximations.

\section{Test examples}

The zero charge flux condition regulates the diffusion of charged ions in the sense that faster ions are retarded and slower ions accelerated. Equation (12) can be shown to provide the Nernst equation for the overall diffusion coefficient of a single-salt solution (Cussler, 1979; Malusis and Shackelford, 2002):

$$
D_{\text {salt }}=\frac{\left(z_{+}-z_{-}\right) D_{+} D_{-}}{z_{+} D_{+}-z_{-} D_{-}}
$$

For example, an overall $D_{\mathrm{NaCl}}=10^{-9} \mathrm{~m}^{2} / \mathrm{s}$ is obtained for $\mathrm{NaCl}$ when $D_{\mathrm{Cl}}=10^{-8} \mathrm{~m}^{2} / \mathrm{s}$, and $D_{\mathrm{Na}}=$ $5.26 \times 10^{-10} \mathrm{~m}^{2} / \mathrm{s}$ (these are example numbers, different from the actual values). The same overall

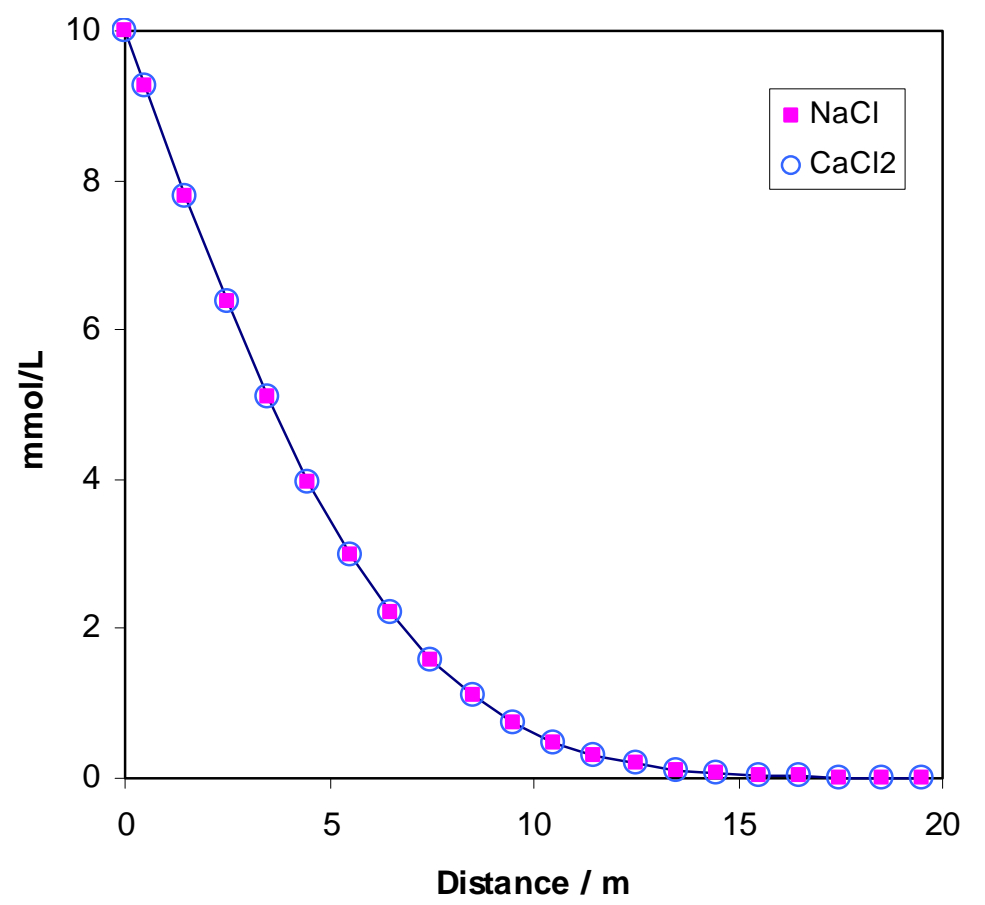

Figure $\mathrm{S} 1 . \mathrm{Cl}^{-}$concentration calculated for $D_{\mathrm{Na}}=D_{\mathrm{Cl}}=10^{-9} \mathrm{~m}^{2} / \mathrm{s}$ (line), and with different diffusion coefficients for $\mathrm{Na}^{+}, \mathrm{Ca}^{2+}$ and $\mathrm{Cl}^{-}$, adjusted to give the same overall $D_{\text {salt }}=$ $10^{-9} \mathrm{~m}^{2} / \mathrm{s}$. 
$D_{\text {salt }}$ is obtained for $\mathrm{CaCl}_{2}$ with the same $D_{\mathrm{Cl}}$, when $D_{\mathrm{Ca}}=3.57 \times 10^{-10} \mathrm{~m}^{2} / \mathrm{s}$. Figure $\mathrm{S} 1$ compares the results for $\mathrm{Cl}^{-}$when the ions have the same or different diffusion coefficients, and shows excellent agreement (the activity coefficients for the ions were made identical).

The results of the Donnan approximation and the complete integration of DDL concentrations are compared in Figure S2. Sodium from a $100 \mathrm{mM} \mathrm{NaCl}$ solution is replaced by equivalent proportions of $\mathrm{Ca}^{2+}$ and $\mathrm{Al}^{3+}$. In each reaction step, the DDL composition of a small surface charge of 10 meq is calculated. The equivalent masses of the cations in the DDL are almost the same with the 2 calculation methods.

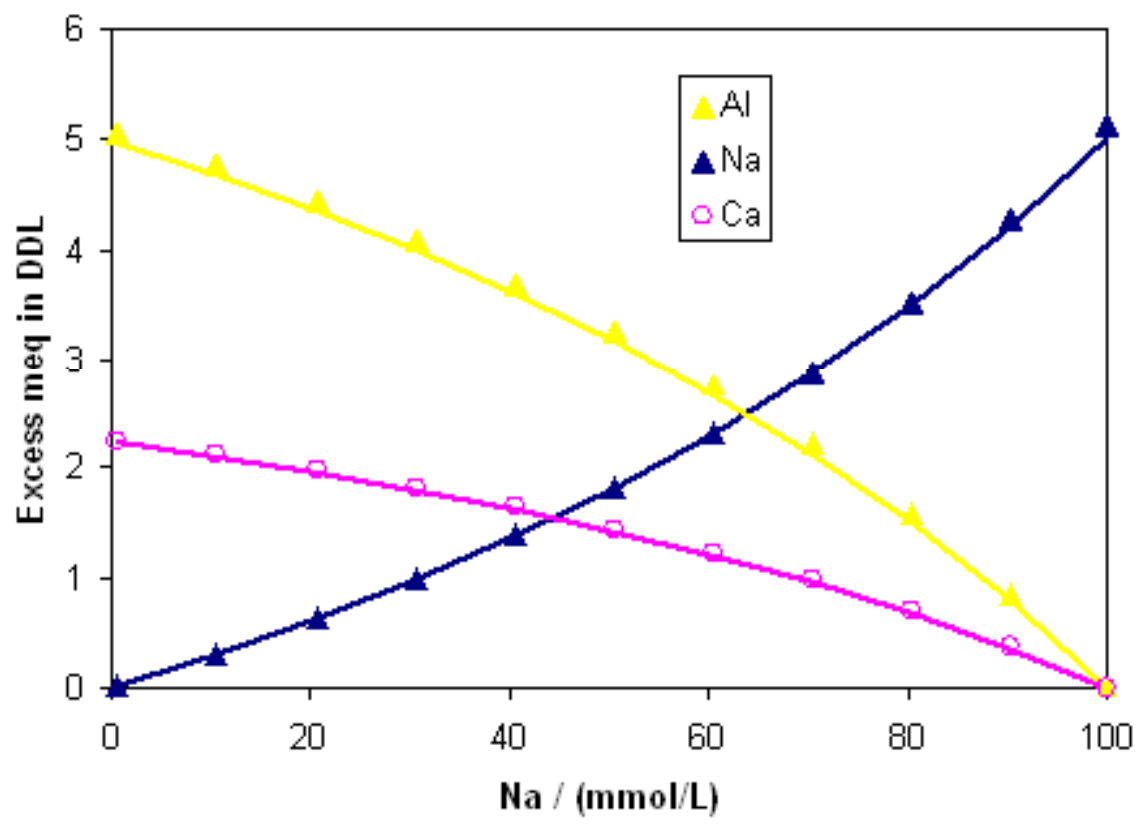

Figure S2. Excess cations in the DDL according to the PHREEQC integration (lines) and the Donnan approximation (symbols). $\mathrm{Na}^{+}$in a $100 \mathrm{mM} \mathrm{NaCl}$ solution (starting composition on the right side of the graph) is stepwise replaced by equivalent amounts of $\mathrm{Ca}^{2+}$ and $\mathrm{Al}^{3+}$ and the excess in the DDL is calculated in each step (the remaining surface charge of 10 meq is balanced by $\mathrm{Cl}^{-}$deficit).

\section{The accessible porosity of Iodide in Opalinus Clay}

Figure S3 shows $\mathrm{I}^{-}$in 3 rock profiles parallel to the bedding in the in-situ experiment, the extrapolated value at $x=0 \mathrm{~cm}(34 \mathrm{mg} / \mathrm{kg})$, and the concentration in the borehole (outer solution) when the profiles were cored $(970 \mathrm{mg} / \mathrm{L})$. In the figure, the outer solution is expressed in $\mathrm{mg} / \mathrm{kg}$ OPA assuming that all of the total porosity contains $\mathrm{I}^{-}:\left(\mathrm{I}^{-}=970 \mathrm{mg} / \mathrm{L} \times\left(\varepsilon_{\mathrm{w}}=0.16\right) /\left(\rho_{\mathrm{b}}=2.27 \mathrm{~kg} / \mathrm{L}\right)=\right) 68$ $\mathrm{mg} / \mathrm{kg}$. The data can be used to assess if sorption of $\mathrm{I}^{-}$occurs, as found by Van Loon et al. (2003).

The accessible porosity for $\mathrm{I}^{-}$is $\varepsilon_{\mathrm{a}\left(\mathrm{I}^{-}\right)}=\left(34 / 970-K_{d}\right) \times\left(\rho_{\mathrm{b}}=2.27 \mathrm{~kg} / \mathrm{L}\right)$.

If $K_{d}=0, \varepsilon_{\mathrm{a}\left(\mathrm{I}^{-}\right)}=0.08$ (50\% of the total porespace).

If $K_{d}=0.014 \mathrm{~L} / \mathrm{kg}$ (which is the highest experimental value for OPA in Mont Terri, Van Loon et al., 2003), $\varepsilon_{\mathrm{a}\left(\mathrm{I}^{-}\right)}=0.045$ (28\% of the total porespace). It seems rather unlikely that the accessible porosity for $\mathrm{I}^{-}$is even smaller than for $\mathrm{Cl}^{-}$(which has similar profiles), which shows that sorption of Iodide is not an issue in this experiment. 


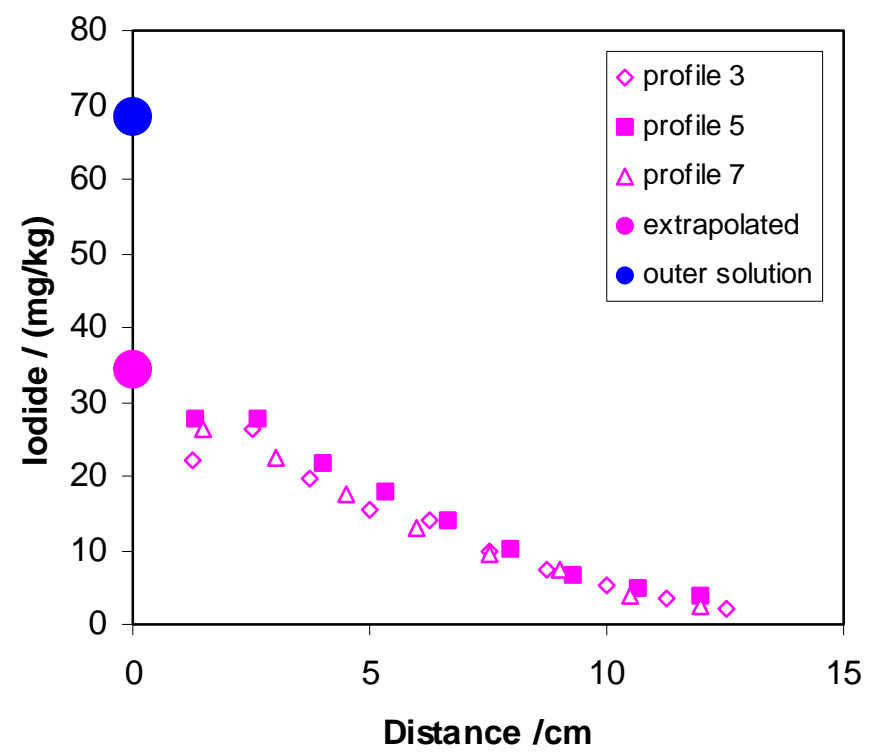

Figure S3. Observed Iodide in 3 rock profiles at the end of the DI A1 diffusion experiment, modeled in the paper. The concentrations in the rock are half of the concentrations in the outer solution in the borehole, which implies that $\varepsilon_{\mathrm{a}\left(\mathrm{I}^{-}\right)}=0.5 \varepsilon_{\mathrm{w}}$.

\section{PHREEQC input files for Figures 3a-d and Figure 4}

The basic data for calculating the mixing factors with Equation (S2) for Figures 3a-d are listed in Table S1.

Table S1. Physical dimensions of the model of the column experiment with Opalinus Clay. $V_{\mathrm{H}_{2} \mathrm{O}}$ is the volume of water in a cell, $V_{0}$ is the volume of the external solution with tracers that contacts the clay, the other parameters are explained with Equation (S2).

$\begin{array}{ccccccccc}\text { length } / \mathrm{m} & A_{i j} / \mathrm{m}^{2} & D_{w} /\left(\mathrm{m}^{2} / \mathrm{s}\right) & \varepsilon & \theta^{2} & \Delta t / \mathrm{s} & h_{i j} / \mathrm{m} & V_{\mathrm{H}_{2} \mathrm{O}} / \mathrm{L} & V_{0} / \mathrm{L} \\ 0.5 & 0.0314 & 2.24 \times 10^{-9} & 0.16 & 6.25 & 6 \times 10^{5} & 0.025 & 0.126 & 0.8\end{array}$

Input files are given in the appendix. If these are run with Vincent Post's PHREEQC for windows (download via links in www.xs4all.nl/ appt) the Figures 3a-d appear directly on screen.

It is of interest to run file Fig $3 \mathrm{~b}$.phrq with the tracer diffusion coefficient of HTO adapted to the value of ${ }^{22} \mathrm{Na}^{+}$or $\mathrm{I}^{-}$, and see that the results are the same, independent of the charge of the tracer, as discussed in the paper. However, that is not the case if the porewater composition is changed to a $1 \mathrm{mM} \mathrm{NaCl}$ solution! Running this modification requires 10 times smaller mixing factors, thus 10 times smaller $\Delta t$ and 10 times more shifts. Now the diffusion of ${ }^{22} \mathrm{Na}^{+}$is higher than of $\mathrm{HTO}$ with the same tracer diffusion coefficient. In this case, the diffusion of a cation at trace concentration is enhanced by electrostatic repulsion by the major cations.

The actual experiment at Mont Terri requires a 3D elliptical grid that follows the outline of the main diffusion field (Appelo, 2006). Again, diffusion is calculated with explicit finite differences, using mixing factors according to Equation (S2). A Pascal program was written that reads parameters from a file, and then prints the PHREEQC input file. By symmetry, only one quarter of the elliptical cylinder is modeled with the outline shown in Figures S4 and S5. 


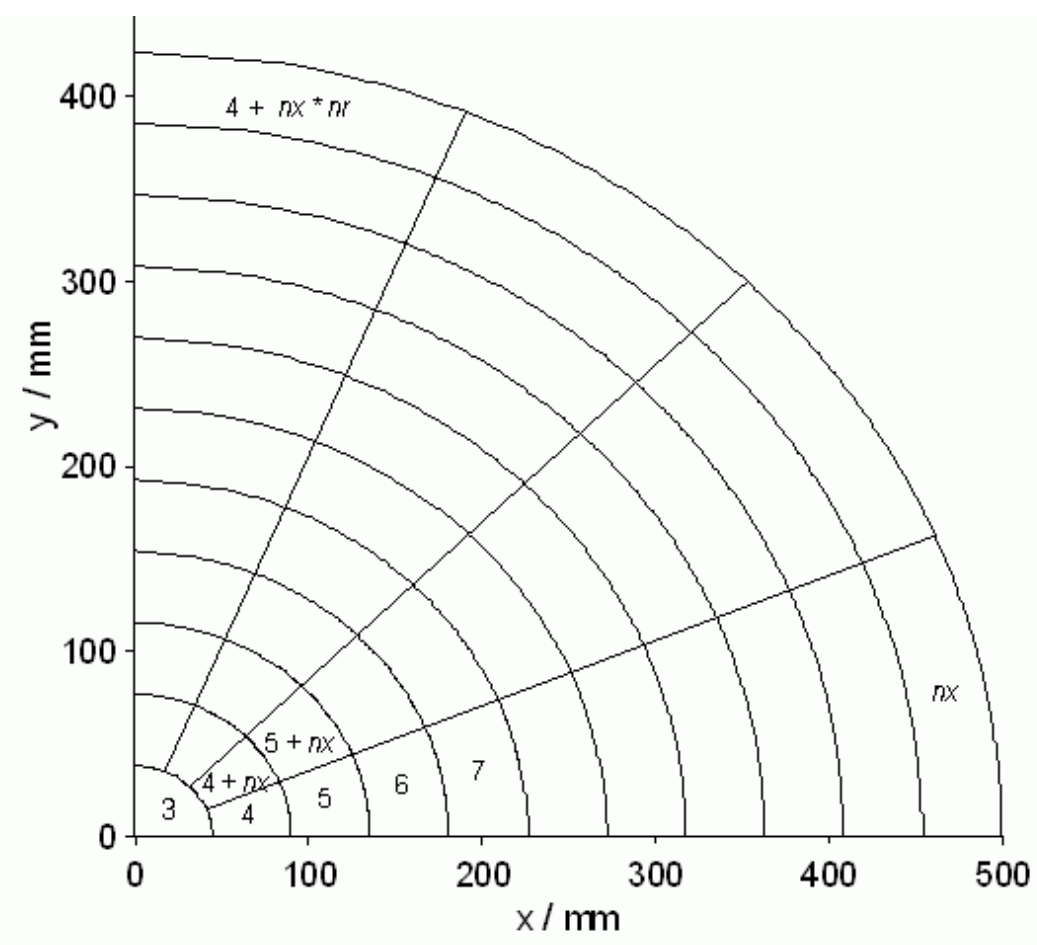

Figure S4. Example of the $x-y$ outline of the elliptical grid for modeling diffusion in the Opalinus Clay with $n x=10$ and $n r=4$. The numbering of the cells is indicated, with cell 3 representing the borehole. For model checking, $n x$ and $n r$ were varied.

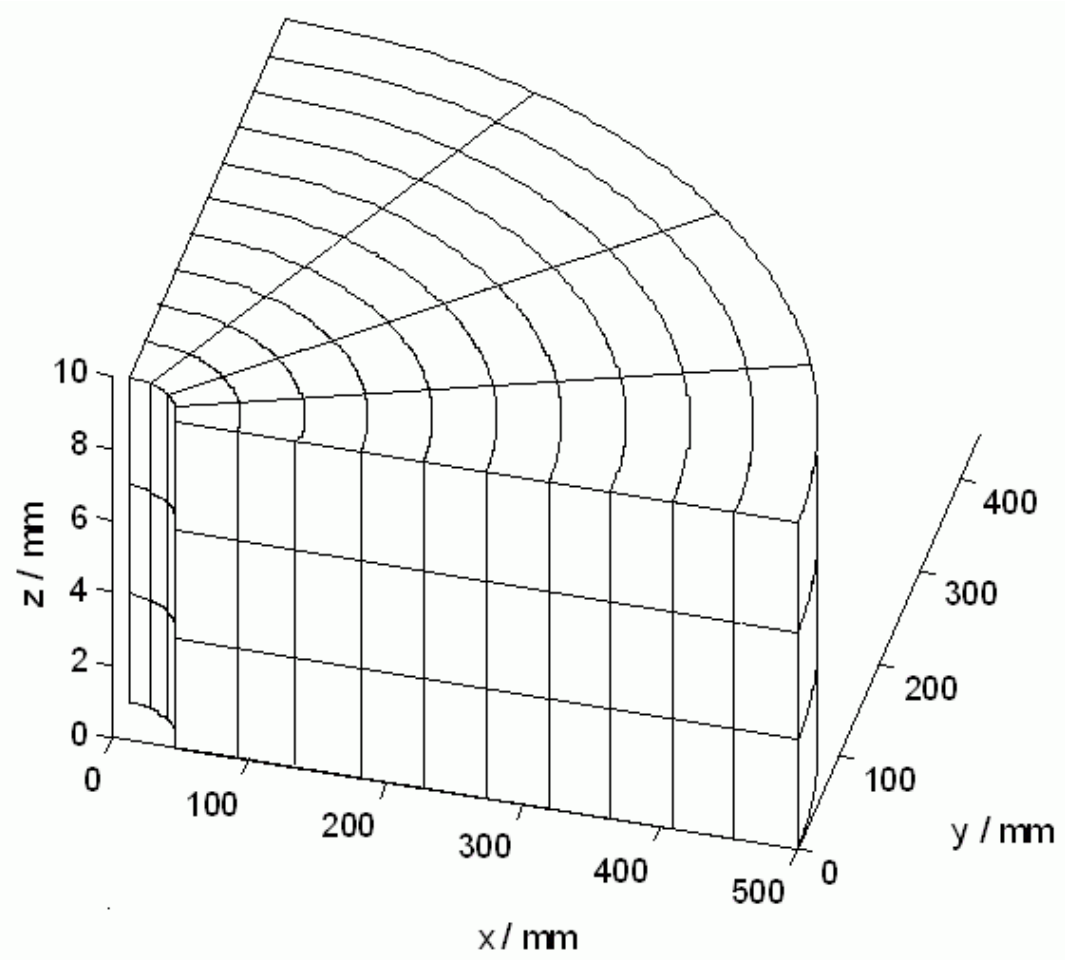

Figure S5. 3D view of an example grid, with $n x=10, n r=4$ and $n z=3$. For model checking, $n x$, $n r$ and $n z$ were varied. 
For the listed file, the model extends $0.44 \mathrm{~m}$ into the clay in the $x$-direction. The discretization can be adapted. The file is made with 3 sectors in the ellipse, each with 40 cells, and 1 layer in the $z$ direction, thus 120 cells in total. SOLUTION 3 is the borehole solution, SOLUTION 4-123 and SURFACE 4-123 are for the clay. The discretization along the outline of the grid is, in the $x$ direction $11 \mathrm{~mm}$, in the $y$-direction $9.33 \mathrm{~mm}$, and in the $z$-direction $9 \mathrm{~mm}$. The cells have different water volumes, of which half is assigned to free porewater with identifier '-water' in keyword SOLUTION, and the other half by setting the surface area in keyword SURFACE with the thickness of the DDL with identifier '-donnan'. A scaling factor is applied to obtain water volumes that fall in a range $(0.01-100 \mathrm{~L})$ which facilitates convergence of the calculations. The surface charge is set homogeneously to $1.6 \mathrm{eq} / \mathrm{L}$ in the file, but it can be distributed heterogeneously over the cells to mimick the heterogeneities in the Opalinus Clay and improve the data-fit as is shown in the paper.

\section{References}

Appelo, C.A.J., 2006. Modeling of HTO-, Na- and Cs-data from a Mont Terri diffusion experiment (DI-A1) with account of heterogeneity of the Opalinus Clay formation and geochemical reactions. Mont Terri Technical Note TN 06-16, Switzerland.

Appelo, C.A.J. and Postma, D., 2005. Geochemistry, groundwater and pollution, $2^{\text {nd }}$ ed. Balkema, Leiden, $649 \mathrm{pp}$.

Atkins, P.W. and de Paula, J., 2002. Atkins' physical chemistry, $7^{\text {th }}$ ed. Oxford UP, 1149 pp.

Cussler, E.L., 1997. Diffusion - mass transfer in fluid systems. Cambridge UP, 525 pp

Grathwohl, P., 1998. Diffusion in natural porous media. Springer, Berlin

Jähne, B., Heinz, G. and Dietrich, W., 1987. Measurement of the diffusion coefficients of sparingly soluble gases in water. J. Geophys. Res. 92, 10767-10776.

Lasaga, A.C., 1998. Kinetic theory in the earth sciences. Princeton UP, 811 pp.

Malusis, M.A. and Shackelford, C.D., 2002. Theory for reactive solute transport through clay membrane barriers. J. Contam. Hydrol. 59, 291-316.

Parkhurst, D.L. and Appelo, C.A.J., 1999. User's guide to PHREEQC (version 2). U.S. Geol. Surv. Water Resour. Inv. Rep. 99-4259, 312 pp.

Pikal, M.J., 1971. Ion-pair formation and the theory of mutual diffusion coefficients in a binary electrolyte. J. Phys. Chem. 75, 663-675.

Robinson, R.A. and Stokes, R.H., 1959. Electrolyte solutions, $2^{\text {nd }}$ ed. Butterworths, London, 559 pp.

Van Loon, L.R., Soler, J.M. and Bradbury, M.H., 2003. Diffusion of HTO, ${ }^{36} \mathrm{Cl}$ and ${ }^{125} \mathrm{I}^{-}$in Opalinus Clay samples from Mont Terri: effect of confining pressure. J. Contam. Hydrol. 61, 73-83.

\section{Appendix}

\section{File for calculating Figure S1}

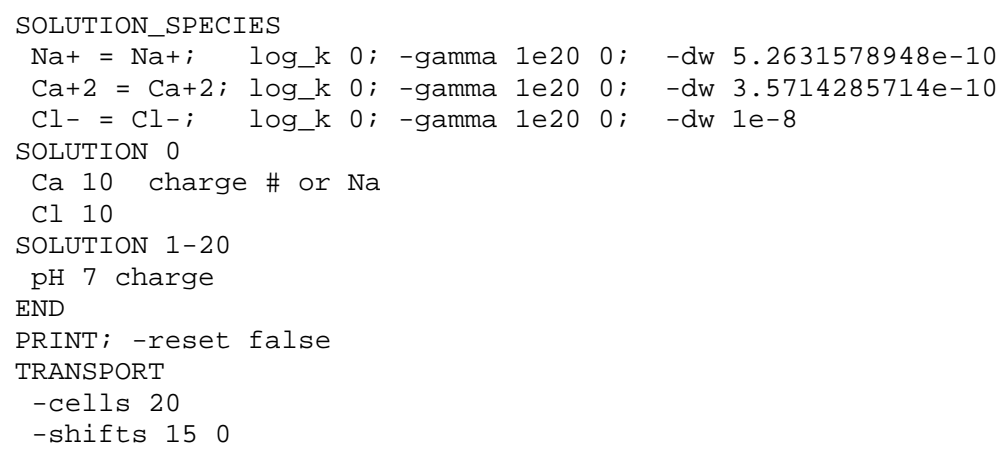




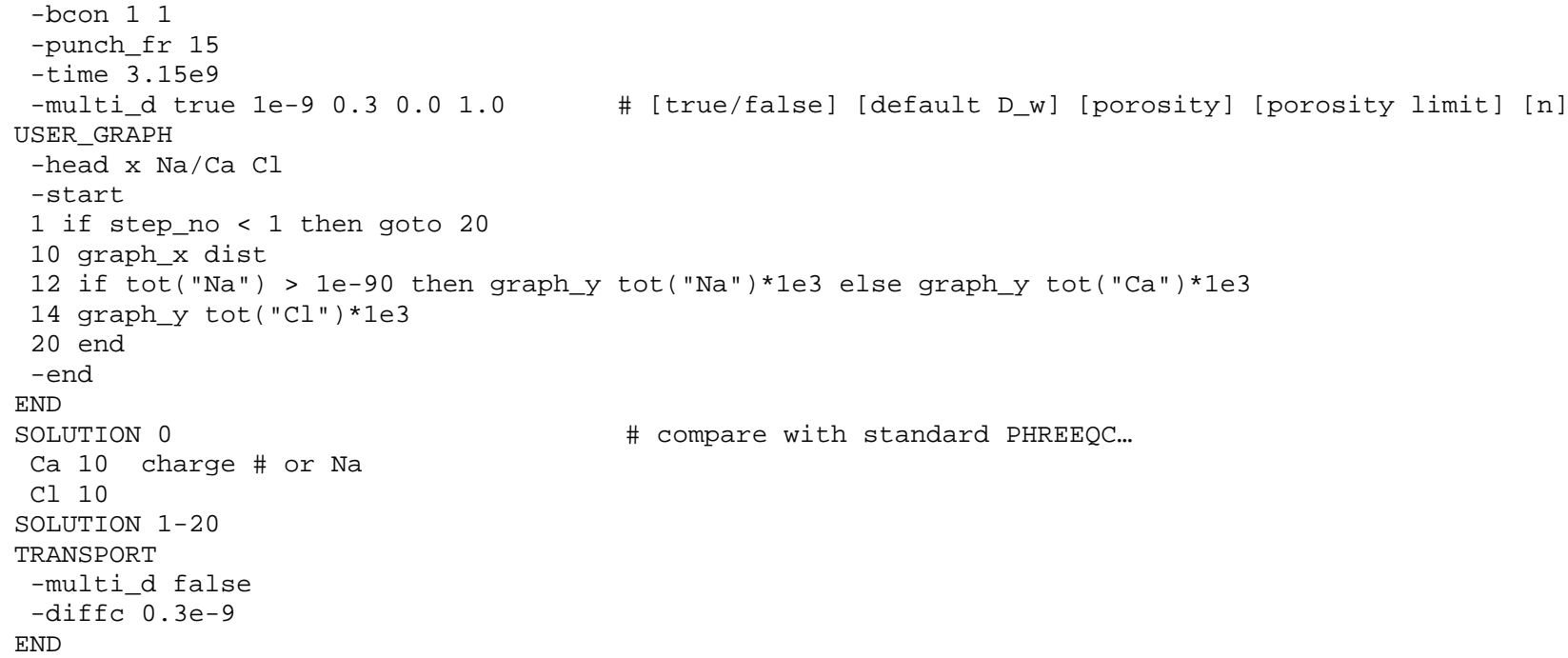

\section{File for calculating Figure S2}

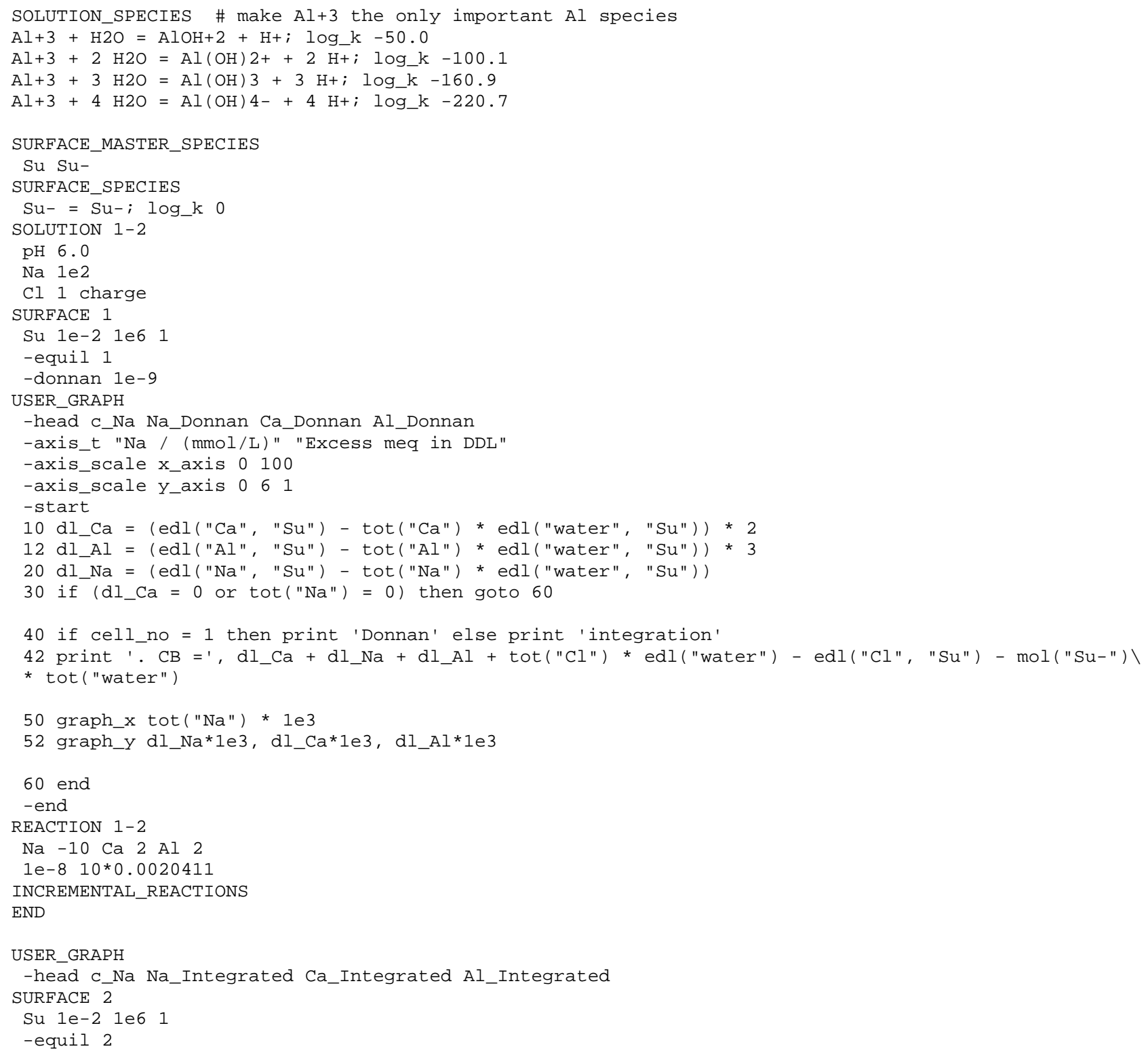




\section{File for calculating Figure 3a}

General for the files for Figure 3, SOLUTION 3 is for the outer solution, SOLUTION 4-23 are for 20 cells in the column.

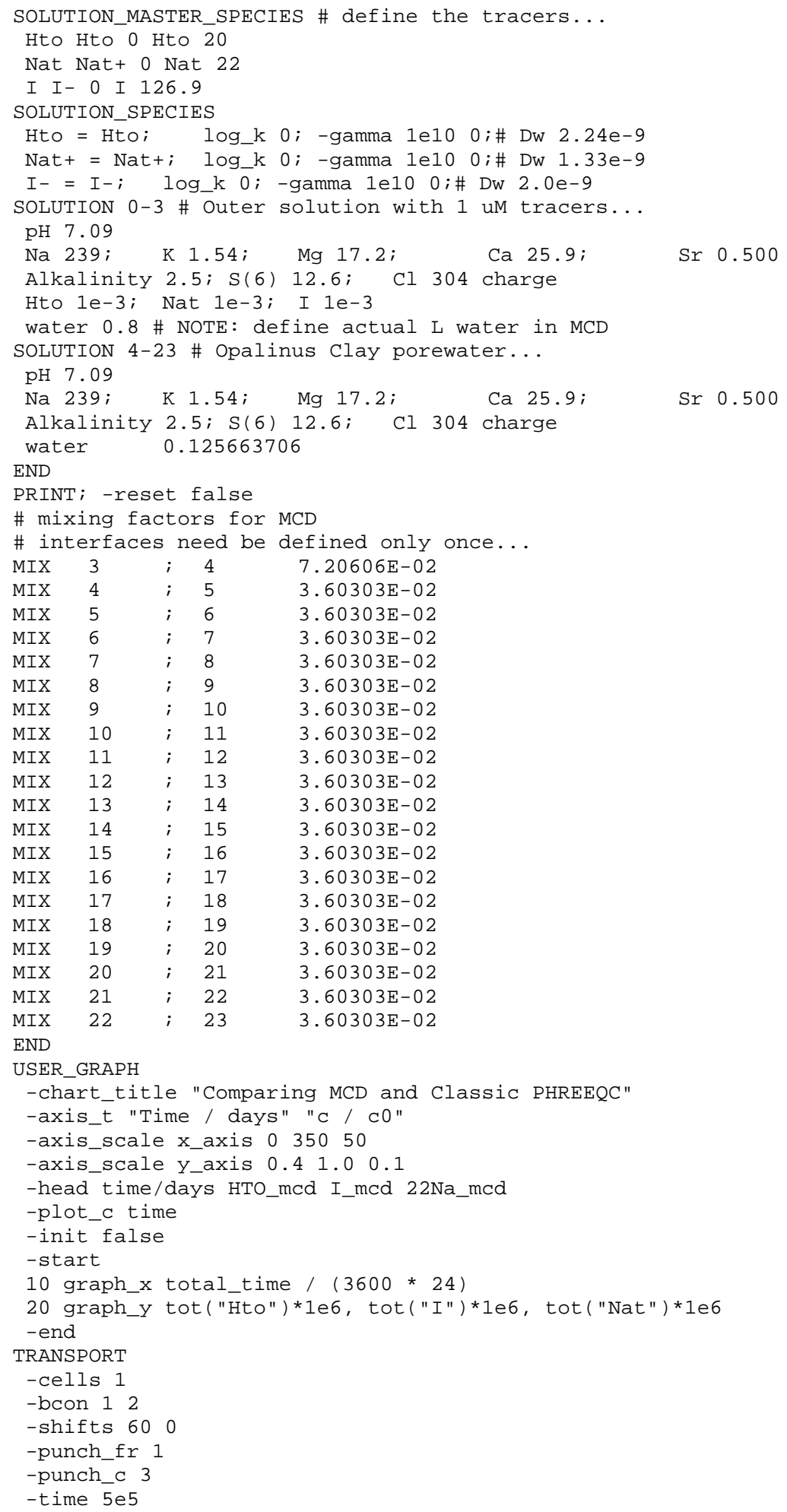




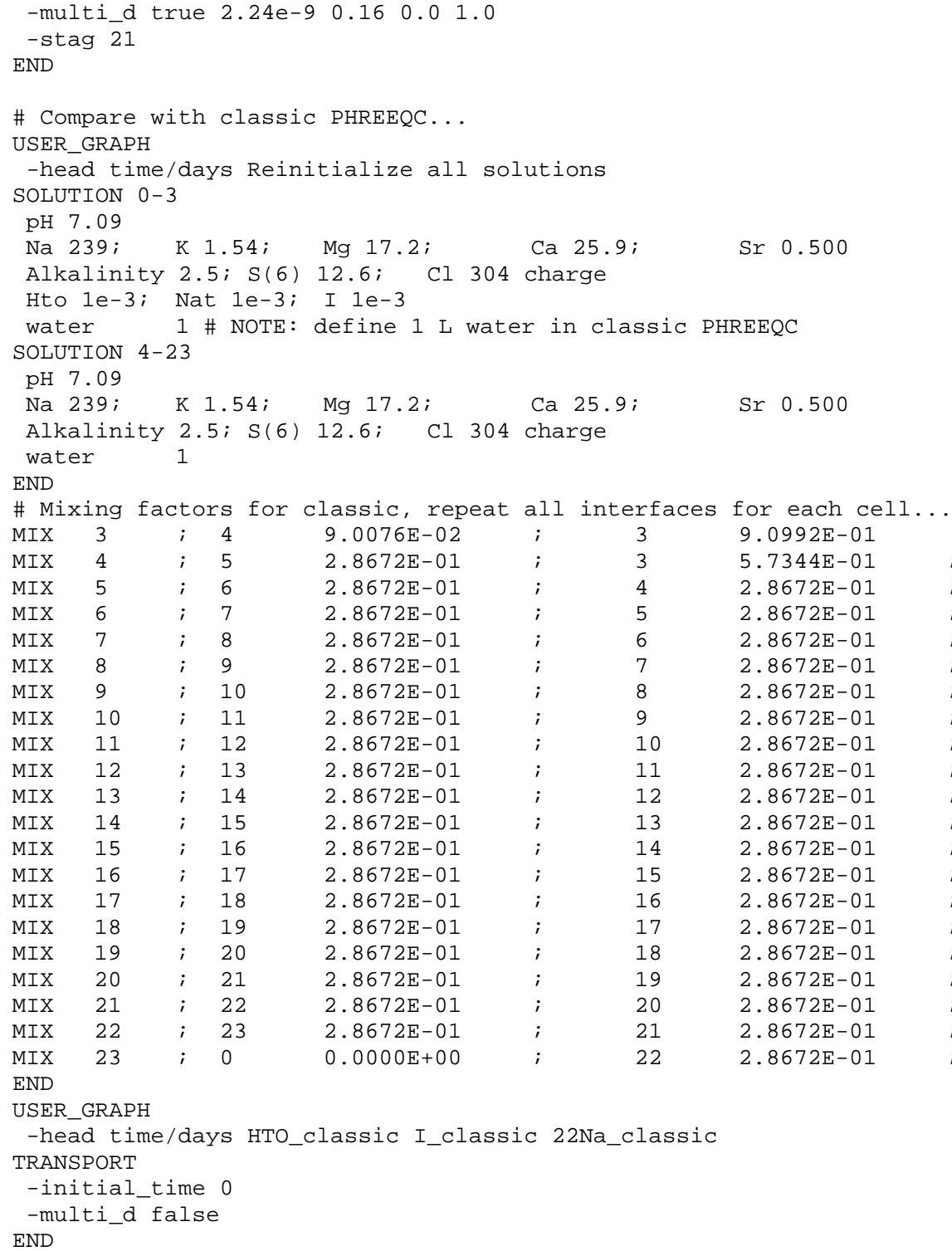

\section{File for calculating Figure $3 \mathbf{b}$}

DATABASE phreeqd.dat

SOLUTION_MASTER_SPECIES \# define the tracers...

Hto Hto 0 Hto 20

Nat Nat+ 0 Nat 22

I I- 0 I 126.9

SOLUTION_SPECIES

Hto = Hto; log $\mathrm{k} 0 ;$-gamma 1 e10 $0 ;$ Dw 2.24e-9

Nat+ $=$ Nat+; log_k $0 ;$-gamma 1 e10 $0 ;$ Dw $1.33 e-9$

I- = I-; log_k 0; -gamma 1 e10 0; Dw $2.0 e-9$

SOLUTION 0-3 \# Outer solution with 1 uM tracers...

$\mathrm{pH} 7.09$

$\mathrm{Na} \mathrm{239;} \quad \mathrm{K} \mathrm{1.54;} \quad$ Mg 17.2; $\quad$ Ca 25.9;

Hto $1 e-3$; Nat $1 e-3$; I $1 e-3$

water 0.8 \# NOTE: define actual $L$ water in MCD

SOLUTION 4-23 \# Opalinus Clay porewater...

$\mathrm{pH} 7.09$

$\mathrm{Na} \mathrm{239;} \quad \mathrm{K} \mathrm{1.54;}$ Mg 17.2; $\quad$ Ca 25.9; $\quad$ Sr 0.500

Alkalinity 2.5; S(6) 12.6; Cl 304 charge

water $\quad 0.125663706$

END

PRINT; -reset false

\# mixing factors for MCD 


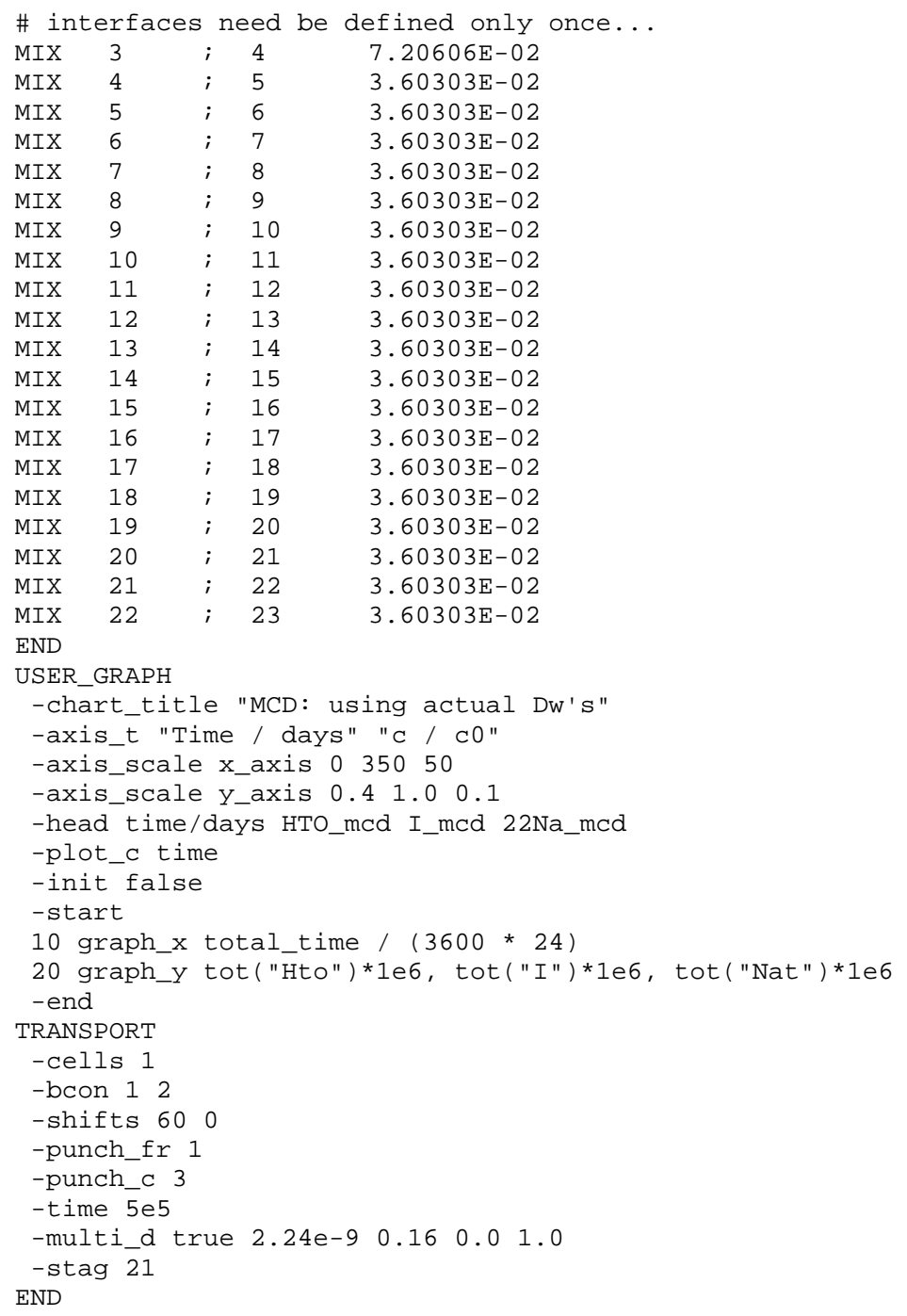

\section{File for calculating Figure 3c}

DATABASE phreeqd.dat

SOLUTION_MASTER_SPECIES \# define the tracers...

Hto Hto 0 Hto 20

Nat Nat+ 0 Nat 22

I I- 0 I 126.9

SOLUTION_SPECIES

Hto = Hto; log_k $0 ;$-gamma 1 e10 $0 ;$ Dw $2.24 \mathrm{e}-9$

Nat $+=$ Nat+; log_k $0 ;$-gamma 1 e10 $0 ;$ Dw $1.33 e-9$

$\mathrm{I}-=\mathrm{I}-; \quad$ log_k $0 ;$-gamma $1 \mathrm{e} 10$ 0; DW $2.0 \mathrm{e}-9$

SOLUTION $0-3$ \# Outer solution with 1 uM tracers...

$\mathrm{pH} 7.09$

Na 239; K 1.54; Mg 17.2; $\quad$ Ca 25.9; $\quad$ Sr 0.500

Alkalinity $2.5 ; \mathrm{S}(6) 12.6 ; \mathrm{Cl} 304$ charge

Hto $1 e-3$; Nat $1 e-3 ;$ I $1 e-3$

water 0.8 \# NOTE: define actual $L$ water in MCD

SOLUTION 4-23 \# Opalinus Clay porewater...

$\mathrm{pH} 7.09$
$\mathrm{Na} \mathrm{239;}$
K 1.54; Mg 17.2;
Ca 25.9;
Sr 0.500
Alkalinity 2.5; S(6) 12.6; Cl 304 charge
water 0.062831853

END

SURFACE 4-43; -equil 4;

-donnan

SURFACE_MASTER_SPECIES; SU Su-

SURFACE_SPECIES; $\quad \mathrm{Su}=\mathrm{Su}-; \quad$ log_k 0

END 


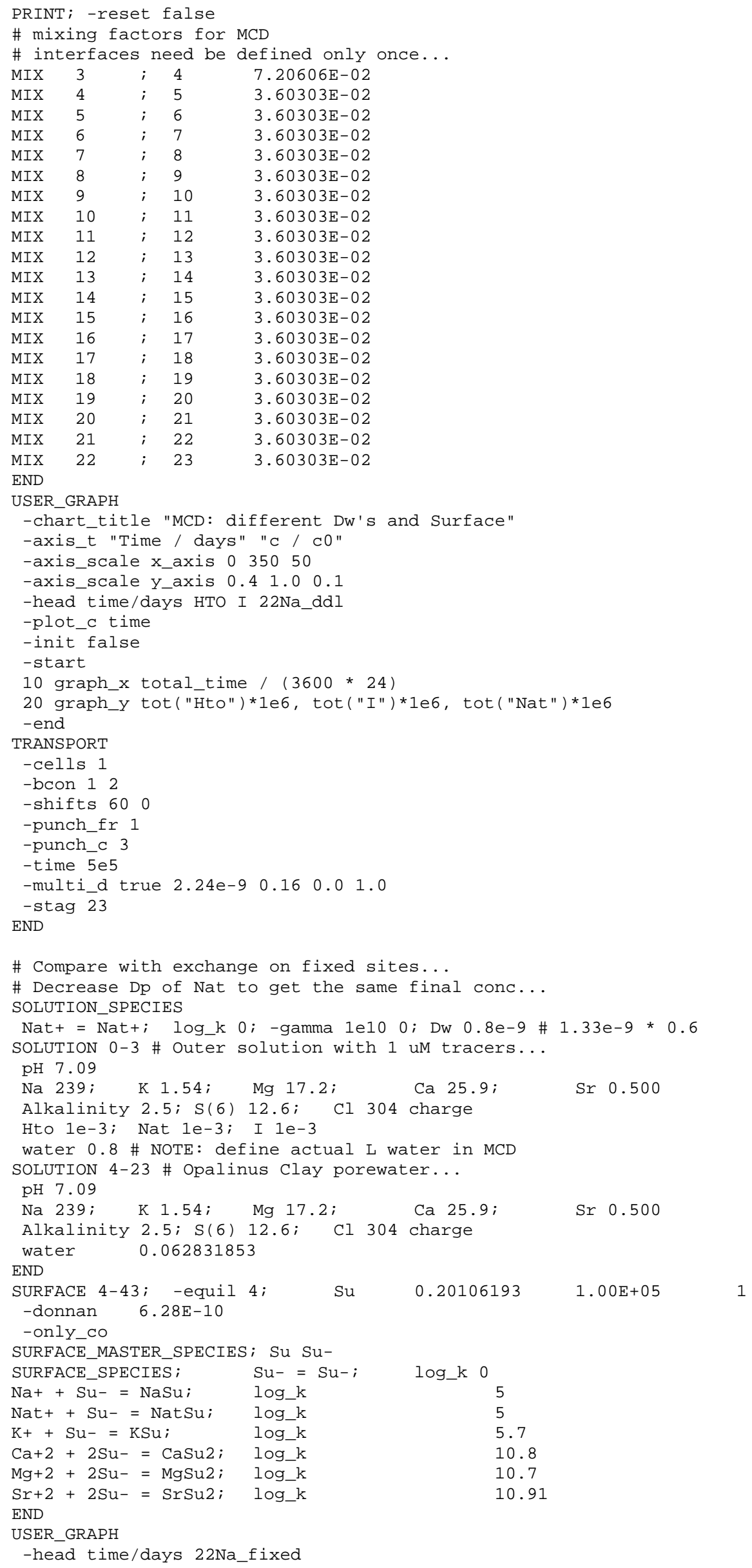




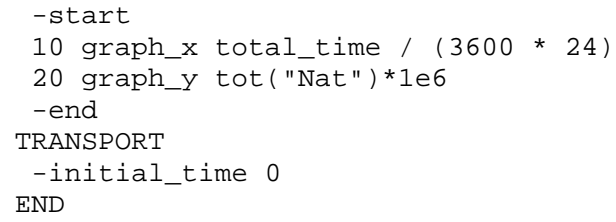

\section{File for calculating Figure 3d}

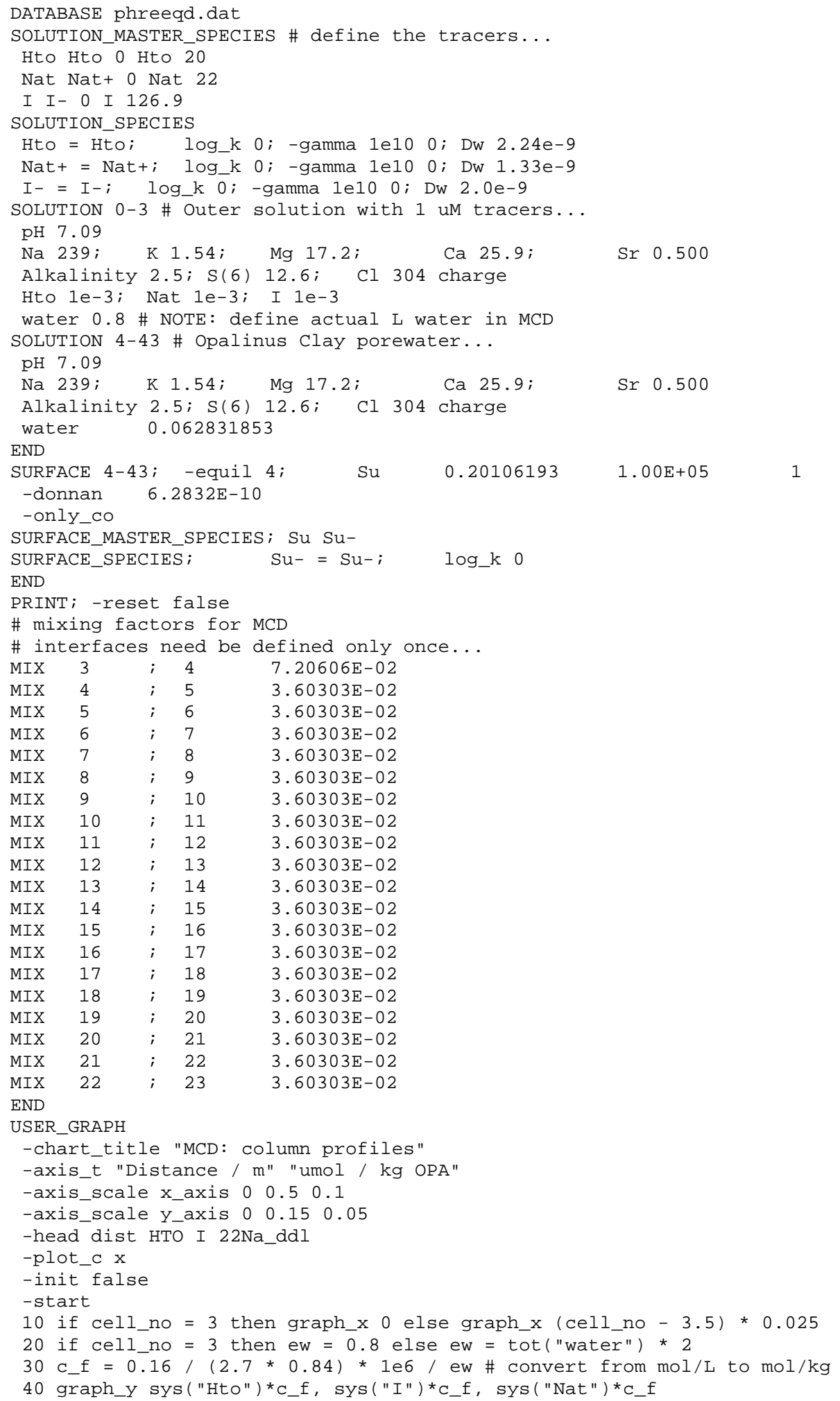




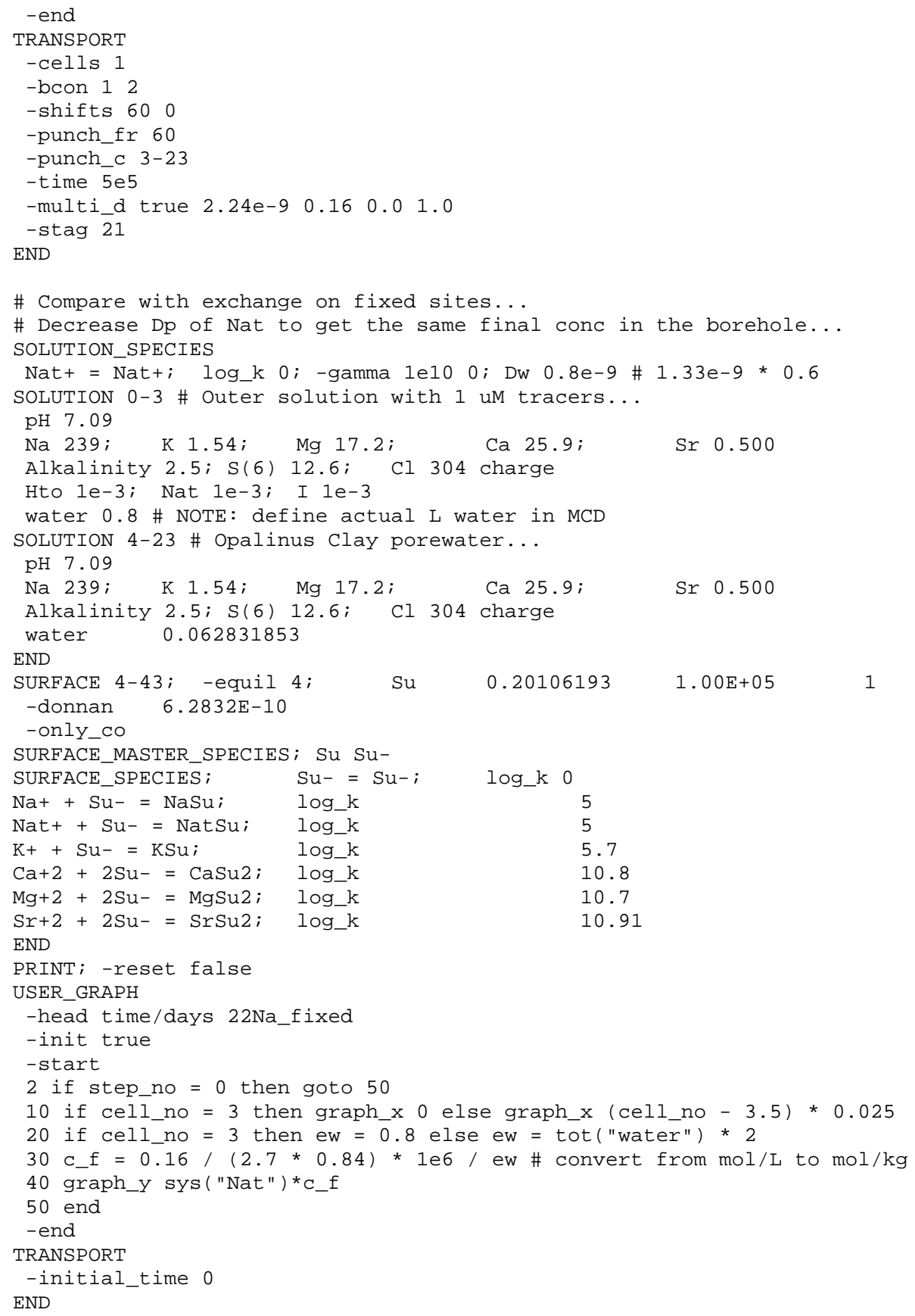

\section{File for calculating Figure 4}

Note how mixing factors for the interfaces among the cells are defined only once with option multi_D. For example, cell 44, the cell in the $2^{\text {nd }}$ sector that borders the borehole, is mixed with the borehole solution (defined in MIX 3), with cell 4 (MIX 4), and with cells 45 and 84 (MIX 44). This file is used for optimizing parameters, and must be run with the UNIX or DOS version of PHREEQC. It writes in file Fig4.txt the concentrations of HTO, ${ }^{22} \mathrm{Na}$ and $\mathrm{I}^{-}$in the borehole solution. Tritium and ${ }^{22} \mathrm{Na}$ are corrected for decay.

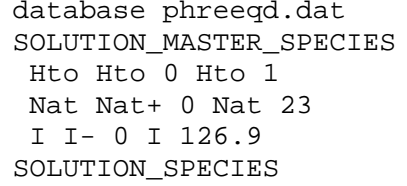




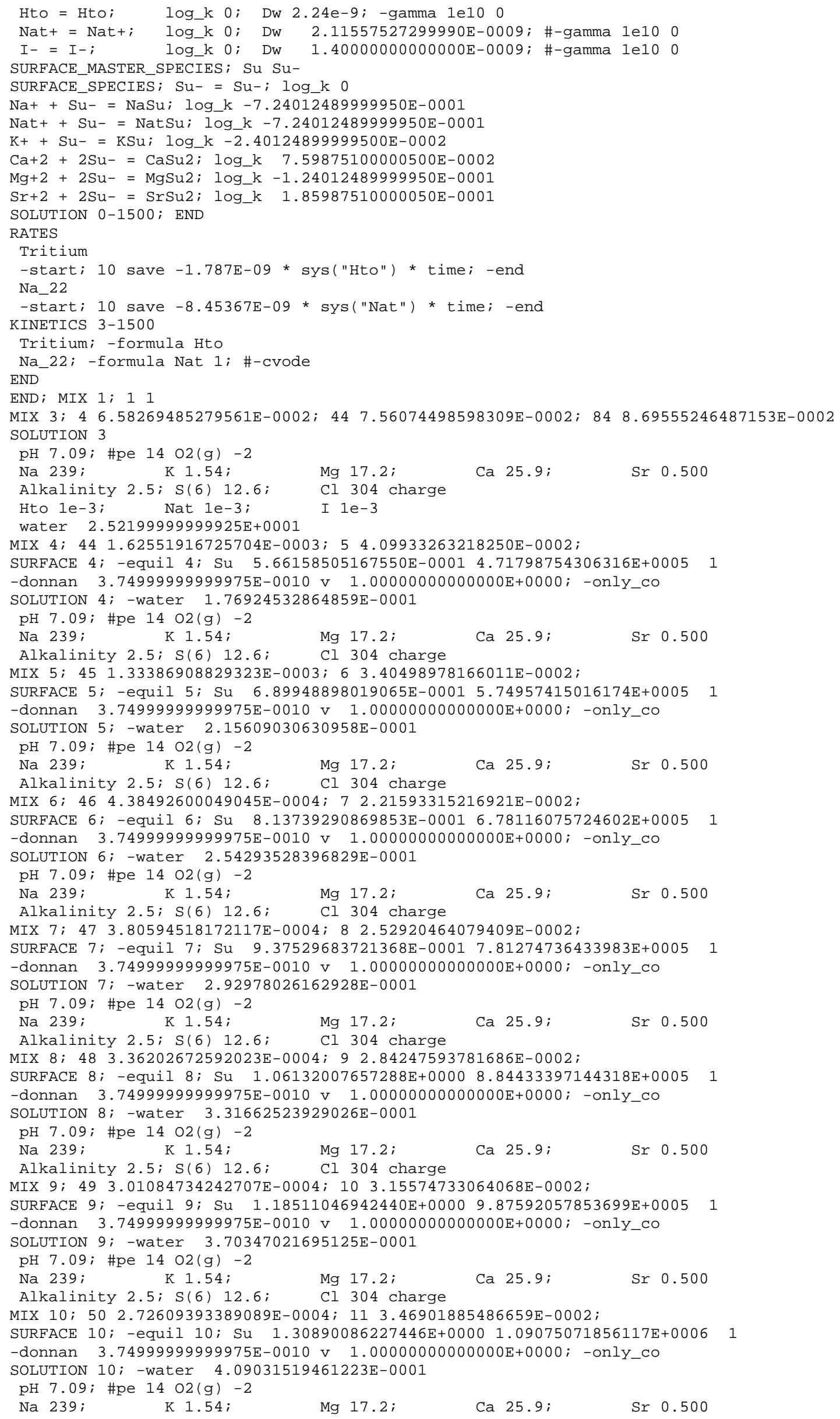




\begin{abstract}
Alkalinity 2.5; S(6) 12.6; Cl 304 charge
\end{abstract}
MIX 11; $512.49054818239358 \mathrm{E}-0004 ; 12$ 3.78229011628832E-0002;

SURFACE 11; -equil 11; Su 1.43269125512597E+0000 1.19390937927246E+0006 1

-donnan 3.74999999999975E-0010 v 1.00000000000000E+0000; -only_co

SOLUTION 11; -water $4.47716017226412 \mathrm{E}-0001$

$\mathrm{pH} 7.09 ;$ \#pe 14 O2 (g) -2

$\mathrm{Na} \mathrm{239; \quad K} \mathrm{1.54;}$

Alkalinity $2.5 ; \mathrm{S}(6) 12.6$;

Mg 17.2;

Ca 25.9;

Sr 0.500

(13 4.09556150910930E-0002;

SURFACE 12; -equil 12; Su 1.55648164797749E+0000 1.29706803998184E+0006 1

-donnan 3.74999999999975E-0010 v 1.00000000000000E+0000; -only_co

SOLUTION 12 ; -water $4.86400514992965 \mathrm{E}-0001$

$\mathrm{pH} 7.09$; \#pe $14 \mathrm{O} 2(\mathrm{~g})-2$
$\mathrm{Na} \mathrm{239;}$
K 1.54 ;
$\operatorname{Mg~17.2;~}$
Ca 25.9;
$\operatorname{Sr} 0.500$

Alkalinity 2.5; S(6) 12.6; Cl 304 charge

MIX 13; $532.12357673041197 \mathrm{E}-0004 ; 144.40883290193028 \mathrm{E}-0002$;

SURFACE 13; -equil 13; Su 1.68027204083046E+0000 1.40022670069122E+0006 1

-donnan 3.74999999999975E-0010 v 1.00000000000000E+0000; -only_co

SOLUTION 13; -water 5.25085012759519E-0001

$\mathrm{pH} 7.09$; \#pe $14 \mathrm{O} 2(\mathrm{~g})-2$
$\mathrm{Na} \mathrm{239;}$
$\mathrm{K} 1.54 ;$
$\operatorname{Mg} 17.2$;
Ca 25.9;
Sr 0.500

Alkalinity $2.5 ; \mathrm{S}(6) 12.6 ; \quad$ Cl 304 charge

MIX 14; $541.97786204187977 \mathrm{E}-0004 ; 154.72210465248963 \mathrm{E}-0002$;

SURFACE 14; -equil 14; Su 1.80406243368052E+0000 1.50338536140060E+0006 1

-donnan 3.74999999999975E-0010 v 1.00000000000000E+0000; -only_co

SOLUTION 14; -water 5.63769510525162E-0001

pH 7.09; \#pe 14 O2 (g) -2
$\mathrm{Na} \mathrm{239;}$
$\mathrm{K} 1.54$;
$\operatorname{Mg} 17.2$;
Ca 25.9 .
$\operatorname{Sr} 0.500$
Alkalinity $2.5 ; \mathrm{S}(6) \quad 12.6 ; \quad$ Cl 304 charge

MIX 15; $551.85086055374128 \mathrm{E}-0004 ; 165.03537568757793 \mathrm{E}-0002$;

SURFACE 15; -equil 15; Su 1.92785282653349E+0000 1.60654402211189E+0006 1

-donnan 3.74999999999975E-0010 v $1.00000000000000 \mathrm{E}+0000$; -only_co

SOLUTION 15; -water $6.02454008291716 \mathrm{E}-0001$

$\mathrm{pH} 7.09 ;$ \#pe $14 \mathrm{O} 2(\mathrm{~g})-2$
$\mathrm{Na} \mathrm{239;}$
K 1.54 ;
$\operatorname{Mg} 17.2$;
Ca 25.9;
Sr 0.500

Alkalinity $2.5 ; \mathrm{S}(6) 12.6 ; \quad$ Cl 304 charge

MIX 16; $561.73918482001412 \mathrm{E}-0004 ; 175.34864708040459 \mathrm{E}-0002$;

SURFACE 16; -equil 16; Su 2.05164321938355E+0000 1.70970268281937E+0006 1

-donnan 3.74999999999975E-0010 v 1.00000000000000E+0000; -only_co

SOLUTION 16; -water 6.41138506057359E-0001

$\mathrm{pH} 7.09$; \#pe $14 \mathrm{O} 2(\mathrm{~g})-2$
$\mathrm{Na} 239$;
K $1.54 ;$
$\operatorname{Mg} 17.2$;
Ca 25.9;
Sr 0.500

Alkalinity $2.5 ; \mathrm{S}(6) 12.6 ; \quad$ Cl 304 charge

MIX 17; $571.64021855176522 \mathrm{E}-0004 ; 185.66191847323125 \mathrm{E}-0002$;

SURFACE 17; -equil 17; Su 2.17543361223361E+0000 1.81286134352875E+0006 1

-donnan $3.74999999999975 \mathrm{E}-0010 \mathrm{~V} 1.00000000000000 \mathrm{E}+0000$; -only_co

SOLUTION 17; -water 6.79823003823003E-0001

pH 7.09; \#pe 14 O2 (g) -2
$\mathrm{Na} \mathrm{239;}$
K 1.54 ;
Mg 17.2;
Alkalinity $2.5 ; \mathrm{S}(6) \quad 12.6 ; \quad$ Cl 304 charge

Ca 25.9;

$\operatorname{Sr} 0.500$

MIX 18; $581.55190913278780 \mathrm{E}-0004 ; 195.97518189766788 \mathrm{E}-0002$;

SURFACE 18; -equil 18; Su 2.29922400508658E+0000 1.91602000423813E+0006 1

-donnan 3.74999999999975E-0010 v 1.00000000000000E+0000; -only_co

SOLUTION 18; -water $7.18507501589556 \mathrm{E}-0001$

pH 7.09; \#pe 14 O2 (g) -2
$\mathrm{Na} 239$;
$\mathrm{K} 1.54$;
$\operatorname{Mg} 17.2$;
Ca 25.9 ;
Sr 0.500

Alkalinity 2.5; S(6) 12.6; Cl 304 charge

MIX 19; $591.47262281097582 \mathrm{E}-0004 ; 206.28846125887321 \mathrm{E}-0002$;

SURFACE 19; -equil 19; Su 2.42301439793664E+0000 2.01917866494751E+0006 1

-donnan 3.74999999999975E-0010 v 1.00000000000000E+0000; -only_co

SOLUTION 19; -water 7.57191999355200E-0001

pH 7.09; \#pe 14 O2 (g) -2
$\mathrm{Na} 239$;
$\mathrm{K} 1.54$
$\operatorname{Mg} 17.2$;
Ca 25.9;
Sr 0.500

Alkalinity $2.5 ; \mathrm{S}(6)$ 12.6; Cl 304 charge

MIX 20; $601.40104433918253 \mathrm{E}-0004 ; 216.60173315183101 \mathrm{E}-0002$;

SURFACE 20; -equil 20; Su 2.54680479078961E+0000 2.12233732565689E+0006 1

-donnan 3.74999999999975E-0010 v $1.00000000000000 \mathrm{E}+0000$; -only_co

SOLUTION 20; -water $7.95876497122663 \mathrm{E}-0001$

$\mathrm{pH} \mathrm{7.09;} \mathrm{\# pe} 14 \mathrm{O} 2(\mathrm{~g})-2$

$\mathrm{Na} \mathrm{239; \quad K} 1.54 ;$

Alkalinity 2.5; S(6) 12.6; $\quad$ Cl 304 charge

MIX 21; $611.33610149100782 \mathrm{E}-0004 ; 226.91500404452654 \mathrm{E}-0002$;

SURFACE 21; -equil 21; Su 2.67059518363967E+0000 2.22549598636627E+0006 1

-donnan 3.74999999999975E-0010 v 1.00000000000000E+0000; -only_co

SOLUTION 21; -water $8.34560994887397 \mathrm{E}-0001$

$\mathrm{pH} 7.09$; \#pe $14 \mathrm{O} 2(\mathrm{~g})-2$
Na 239;
$\mathrm{K} 1.54$;
$\operatorname{Mg} 17.2$;
Ca 25.9;
Sr 0.500 
Alkalinity 2.5; S(6) 12.6; Cl 304 charge

MIX 22; $621.27691257957530 \mathrm{E}-0004 ; 237.22827543734184 \mathrm{E}-0002$;

SURFACE 22; -equil 22; Su 2.79438557648973E+0000 2.32865464707565E+0006 1

-donnan $3.74999999999975 \mathrm{E}-0010 \mathrm{~V} 1.00000000000000 \mathrm{E}+0000$; -only_co

SOLUTION 22; -water $8.73245492653041 \mathrm{E}-0001$

$\mathrm{pH} 7.09 ;$ \#pe $14 \mathrm{O} 2(\mathrm{~g})-2$

$\mathrm{Na} 239 ; \quad \mathrm{K} 1.54$;

Alkalinity $2.5 ; \mathrm{S}(6) 12.6$;

Mg 17.2;

Ca 25.9;

Sr 0.500

. $24 \quad 1.34962976378347 \mathrm{E}-0001$ i

SURFACE 23; -equil 23; Su 2.91817596934270E+0000 2.43181330778503E+0006 1

-donnan 3.74999999999975E-0010 v 1.00000000000000E+0000; -only_co

SOLUTION 23; -water 9.11929990419594E-0001

$\mathrm{pH} 7.09$; \#pe 14 O2 (g) -2
$\mathrm{Na} 239$;
$\mathrm{K} 1.54$;
Mg 17.2;
Ca 25.9;
Sr 0.500

Alkalinity $2.5 ; \mathrm{S}(6) \quad 12.6 ; \quad$ Cl 304 charge

MIX 24; $643.02535036754392 \mathrm{E}-0004 ; 252.02590334882871 \mathrm{E}-0001$;

SURFACE 24; -equil 24; Su 3.04196636219276E+0000 2.53497196849442E+0006 1

-donnan $3.74999999999975 \mathrm{E}-0010 \mathrm{~V} 1.00000000000000 \mathrm{E}+0000$; -only_co

SOLUTION 24 ; -water $9.50614488185238 \mathrm{E}-0001$

$\mathrm{pH} 7.09$; \#pe $14 \mathrm{O} 2(\mathrm{~g})-2$
$\mathrm{Na} 239$;
$\mathrm{K} 1.54$;
$\operatorname{Mg} 17.2$;
Ca 25.9;
Sr 0.500

Alkalinity $2.5 ; \mathrm{S}(6)$ 12.6; Cl 304 charge

MIX 25; 65 2.90705038716155E-0004; $261.46175540734703 \mathrm{E}-0001$;

SURFACE 25; -equil 25; Su 3.16575675504573E+0000 2.63813062920380E+0006 1

-donnan $3.74999999999975 \mathrm{E}-0010 \mathrm{~V} 1.00000000000000 \mathrm{E}+0000$; -only_co

SOLUTION 25; -water $9.89298985951791 \mathrm{E}-0001$

pH 7.09; \#pe 14 O2 (g) -2
$\mathrm{Na} \mathrm{239;}$
$\mathrm{K} 1.54$;
$\operatorname{Mg} 17.2$;
Ca 25.9;
Sr 0.500
Alkalinity 2.5; S(6) 12.6; Cl 304 charge

MIX 26; 66 1.08470447236542E-0004; $278.48136165117239 \mathrm{E}-0002$;

SURFACE 26; -equil 26; Su 3.28954714789870E+0000 2.74128928991699E+0006 1

-donnan $3.74999999999975 \mathrm{E}-0010 \mathrm{~V} 1.00000000000000 \mathrm{E}+0000$; -only_co

SOLUTION 26; -water $1.02798348371834 \mathrm{E}+0000$

pH 7.09; \#pe 14 O2 (g) -2
$\mathrm{Na} 239$;
K 1.54 ;
$\operatorname{Mg} 17.2$;
Ca 25.9;
Sr 0.500

Alkalinity $2.5 ; \mathrm{S}(6) 12.6 ; \quad$ Cl 304 charge

MIX 27; $671.04536586086645 \mathrm{E}-0004 ; 28$ 8.79463173519071E-0002;

SURFACE 27; -equil 27; Su 3.41333754074876E+0000 2.84444795062256E+0006 1

-donnan $3.74999999999975 \mathrm{E}-0010 \mathrm{~V} 1.00000000000000 \mathrm{E}+0000$; -only_co

SOLUTION 27; -water $1.06666798148399 \mathrm{E}+0000$

$\mathrm{pH} 7.09 ;$ \#pe $14 \mathrm{O} 2(\mathrm{~g})-2$
$\mathrm{Na} 239$;
$\mathrm{K} 1.54$;
$\operatorname{Mg} 17.2$;
Ca 25.9;
$\operatorname{Sr} 0.500$

Alkalinity $2.5 ; \mathrm{S}(6) 12.6 ; \quad$ Cl 304 charge

MIX 28; $681.00878073389765 \mathrm{E}-0004 ; 29$ 9.10790448427861E-0002;

SURFACE 28; -equil 28; Su 3.53712793359882E+0000 2.94760661133194E+0006 1

-donnan 3.74999999999975E-0010 v $1.00000000000000 \mathrm{E}+0000$; -only_co

SOLUTION 28; -water $1.10535247924963 \mathrm{E}+0000$

pH 7.09; \#pe 14 O2 (g) -2
$\mathrm{Na} \mathrm{239;}$
K 1.54 ;
Mg 17.2;
Alkalinity $2.5 ; \mathrm{S}(6) \quad 12.6 ; \quad$ Cl 304 charge

Ca 25.9 ;

Sr 0.500

MIX 29; $699.74669802856099 \mathrm{E}-0005 ; 309.42117590083171 \mathrm{E}-0002$;

SURFACE 29; -equil 29; Su 3.66091832644888E+0000 3.05076527204132E+0006 1

-donnan 3.74999999999975E-0010 v 1.00000000000000E+0000; -only_co

SOLUTION 29; -water $1.14403697701528 \mathrm{E}+0000$

$\mathrm{pH} 7.09$; \#pe $1402(\mathrm{~g})-2$
$\mathrm{Na} 239$;
$\mathrm{K} 1.54$;
$\operatorname{Mg} 17.2$;
Ca 25.9 ;
Sr 0.500

Alkalinity 2.5; S(6) 12.6; Cl 304 charge

MIX 30; 70 9.42790223356305E-0005; $319.73444584245726 \mathrm{E}-0002$;

SURFACE 30; -equil 30; Su 3.78470871929894E+0000 3.15392393275070E+0006 1

-donnan $3.74999999999975 \mathrm{E}-0010 \mathrm{~V} 1.00000000000000 \mathrm{E}+0000$; -Only_co

SOLUTION 30 ; -water $1.18272147478092 \mathrm{E}+0000$

pH 7.09; \#pe 14 O2 (g) -2
$\mathrm{Na} 239$;
$\mathrm{K} 1.54$;
$\operatorname{Mg} 17.2$;
Ca 25.9;
Sr 0.500

Alkalinity 2.5; S(6) 12.6; Cl 304 charge

MIX 31; $719.12930116410138 \mathrm{E}-0005$; 32 1.00477187339720E-0001;

SURFACE 31; -equil 31; Su 3.90849911214900E+0000 3.25708259345627E+0006 1

-donnan 3.74999999999975E-0010 v 1.00000000000000E+0000; -only_co

SOLUTION 31; -water $1.22140597254656 \mathrm{E}+0000$

pH 7.09; \#pe $1402(\mathrm{~g})-2$

Na 239; $\quad$ K 1.54; $\quad$ Mg 17.2; $\quad$ Ca 25.9;

Alkalinity $2.5 ; \mathrm{S}(6) \quad 12.6 ; \quad$ Cl 304 charge

MIX 32; 72 8.84903326074493E-0005; $331.03609885806350 \mathrm{E}-0001$;

SURFACE 32; -equil 32; Su 4.03228950499906E+0000 3.36024125416565E+0006 1

-donnan 3.74999999999975E-0010 V 1.00000000000000E+0000; -Only_co

SOLUTION 32; -water $1.26009047031221 \mathrm{E}+0000$

$\mathrm{pH} 7.09$; \#pe $14 \mathrm{O} 2(\mathrm{~g})-2$
Na 239;
$\mathrm{K} 1.54$;
$\operatorname{Mg} 17.2$;
Ca 25.9;
Sr 0.500 
Alkalinity 2.5; S(6) 12.6 ;

Cl 304 charge

MIX 33; $738.58546145936501 \mathrm{E}-0005 ; 341.06742615670555 \mathrm{E}-0001$;

SURFACE 33; -equil 33; Su 4.15607989785494E+0000 3.46339991487885E+0006 1

-donnan 3.74999999999975E-0010 v 1.00000000000000E+0000; -only_co

SOLUTION 33; -water $1.29877496807967 \mathrm{E}+0000$

pH 7.09; \#pe 14 O2 (g) -2

$\mathrm{Na} 239 ; \quad \mathrm{K} \mathrm{1.54;} \quad \mathrm{Mg} \mathrm{17.2;} \quad \mathrm{Ca} 25.9 ; \quad$ Sr 0.500

Alkalinity 2.5; S(6) 12.6; Cl 304 charge

MIX 34; $748.33713719671003 \mathrm{E}-0005 ; 351.09875313188240 \mathrm{E}-0001$;

SURFACE 34; -equil 34; Su 4.27987029070500E+0000 3.56655857558823E+0006 1

-donnan 3.74999999999975E-0010 v $1.00000000000000 \mathrm{E}+0000$; -only_co

SOLUTION 34; -water $1.33745946584531 \mathrm{E}+0000$

pH 7.09; \#pe 14 O2 (g) -2

$\mathrm{Na} \mathrm{239;} \quad \mathrm{K} 1.54 ; \quad$ Mg 17.2; $\quad$ Ca 25.9; $\quad$ Sr 0.500

Alkalinity 2.5; S(6) 12.6; Cl 304 charge

MIX 35; $758.10277361432021 \mathrm{E}-0005 ; 361.13008044001731 \mathrm{E}-0001$;

SURFACE 35; -equil 35; Su 4.40366068355506E+0000 3.66971723629379E+0006

-donnan $3.74999999999975 \mathrm{E}-0010 \mathrm{v} 1.00000000000000 \mathrm{E}+0000$; -only_co

SOLUTION 35; -water $1.37614396361096 \mathrm{E}+0000$

$\mathrm{pH} 7.09 ;$ \#pe $14 \mathrm{O} 2(\mathrm{~g})-2$
$\mathrm{Na} \mathrm{239;}$
$\mathrm{K} 1.54$;
Mg 17.2;
Ca 25.9;
Sr 0.500

Alkalinity 2.5; S(6) 12.6; Cl 304 charge

MIX 36; $767.88122579565176 \mathrm{E}-0005$; 37 1.16140758167262E-0001;

SURFACE 36; -equil 36; Su 4.52745107641094E+0000 3.77287589700699E+0006 1

-donnan $3.74999999999975 \mathrm{E}-0010 \mathrm{~V} 1.00000000000000 \mathrm{E}+0000$; -only co

SOLUTION 36; -water $1.41482846137842 \mathrm{E}+0000$

$\mathrm{pH} 7.09 ;$ \#pe $14 \mathrm{O} 2(\mathrm{~g})-2$

$\mathrm{Na} \mathrm{239; \quad K} \mathrm{1.54;}$

Alkalinity $2.5 ; \mathrm{S}(6) 12.6$;

$\operatorname{Mg} 17.2$;

Ca 25.9;

$\operatorname{Sr} 0.500$

SURFACE 37; -equil 37; Su 4.65124146925518E+0000 3.87603455771255E+0006 1

-donnan 3.74999999999975E-0010 v $1.00000000000000 \mathrm{E}+0000$; -only_co

SOLUTION 37; -water $1.45351295914224 \mathrm{E}+0000$

$\mathrm{pH} 7.09 ;$ \#pe $14 \mathrm{O} 2(\mathrm{~g})-2$
$\mathrm{Na} \mathrm{239;}$
$\mathrm{K} 1.54$
$\operatorname{Mg} 17.2$;
Ca 25.9;
$\operatorname{Sr} 0.500$

Alkalinity 2.5; S(6) 12.6; Cl 304 charge

MIX 38; $787.47259203147443 \mathrm{E}-0005 ; 391.22406186498324 \mathrm{E}-0001$;

SURFACE 38; -equil 38; Su 4.77503186211106E+0000 3.97919321842575E+0006

-donnan 3.74999999999975E-0010 v 1.00000000000000E+0000; -only_co

SOLUTION 38; -water $1.49219745690971 \mathrm{E}+0000$

$\mathrm{pH} 7.09$; \#pe $14 \mathrm{O} 2(\mathrm{~g})-2$

$\begin{array}{lllll}\mathrm{Na} \mathrm{239;} \quad \mathrm{K} \mathrm{1.54;} & \text { Mg 17.2; } & \text { Ca 25.9; } & \text { Sr } 0.500\end{array}$

Alkalinity 2.5; S(6) 12.6; Cl 304 charge

MIX 39; $797.28376432384437 \mathrm{E}-0005 ; 401.25538881642797 \mathrm{E}-0001$;

SURFACE 39; -equil 39; Su 4.89882225496112E+0000 4.08235187913513E+0006 1

-donnan 3.74999999999975E-0010 v 1.00000000000000E+0000; -only_co

SOLUTION 39; -water $1.53088195467535 \mathrm{E}+0000$

$\mathrm{pH} \mathrm{7.09;} \mathrm{\# pe} 14 \mathrm{O} 2(\mathrm{~g})-2$

$\mathrm{Na} \mathrm{239; \quad K} 1.54 ;$

Alkalinity $2.5 ; \mathrm{S}(6) 12.6$;

$\operatorname{Mg} 17.2$;

Ca 25.9;

$\operatorname{Sr} 0.500$

SURFACE 40; -equil 40; Su 5.02261264781700E+0000 4.18551053984833E+0006 1

-donnan 3.74999999999975E-0010 v $1.00000000000000 \mathrm{E}+0000$; -only_co

SOLUTION 40; -water $1.56956645244281 \mathrm{E}+0000$

$\mathrm{pH} 7.09 ;$ \#pe $14 \mathrm{O} 2(\mathrm{~g})-2$

$\mathrm{Na} \mathrm{239; \quad K} \mathrm{1.54; \quad Mg} \mathrm{17.2; \quad Ca} \mathrm{25.9;}$

Alkalinity 2.5; S(6) 12.6; Cl 304 charge

MIX 41; $816.93336006637679 \mathrm{E}-0005 ; 421.31804328995031 \mathrm{E}-0001$;

SURFACE 41; -equil 41; Su 5.14640304066124E+0000 4.28866920055389E+0006 1

-donnan 3.74999999999975E-0010 v 1.00000000000000E+0000; -only_co

SOLUTION 41; -water $1.60825095020482 \mathrm{E}+0000$

$\mathrm{pH} \mathrm{7.09;} \mathrm{\# pe} 1402(\mathrm{~g})-2$

Na 239; K 1.54; Mg 17.2; Ca 25.9; $\quad$ Sr 0.500

Alkalinity $2.5 ; \mathrm{S}(6)$ 12.6; Cl 304 charge

MIX 42; $826.77050370115673 \mathrm{E}-0005 ; 431.34937022715349 \mathrm{E}-0001$;

SURFACE 42; -equil 42; Su 5.27019343351712E+0000 4.39182786126709E+0006 1

-donnan $3.74999999999975 \mathrm{E}-0010 \mathrm{~V} \quad 1.00000000000000 \mathrm{E}+0000$; -only_co

SOLUTION 42; -water $1.64693544797228 \mathrm{E}+0000$

$\mathrm{pH} 7.09 ;$ \#pe $14 \mathrm{O} 2(\mathrm{~g})-2$

$\mathrm{Na} 239 ; \quad \mathrm{K} \mathrm{1.54;} \quad$ Mg 17.2; $\quad$ Ca 25.9; $\quad$ Sr 0.500

Alkalinity $2.5 ; \mathrm{S}(6) \quad 12.6 ; \quad$ Cl 304 charge

MIX 43; $836.61512304849232 \mathrm{E}-0005$;

SURFACE 43; -equil 43; Su 5.39398382636718E+0000 4.49498652197266E+0006

-donnan $3.74999999999975 \mathrm{E}-0010 \mathrm{v} \quad 1.00000000000000 \mathrm{E}+0000$; -only_co

SOLUTION 43; -water $1.68561994573975 \mathrm{E}+0000$

$\mathrm{pH} 7.09 ;$ \#pe $1402(\mathrm{~g})-2$

Na 239; $\quad$ K 1.54; $\quad$ Mg 17.2; $\quad$ Ca 25.9; 
Na 239; $\quad$ K 1.54; $\quad$ Mg 17.2; $\quad$ Ca 25.9; $\quad$ Sr 0.500

Alkalinity $2.5 ; \mathrm{S}(6) \quad 12.6 ; \quad$ Cl 304 charge

MIX 45; $851.13244335819473 \mathrm{E}-0003 ; 463.91090111787662 \mathrm{E}-0002$;

SURFACE 45; -equil 45; Su 6.89948898019065E-0001 5.74957415016174E+0005 1

-donnan 3.74999999999975E-0010 v 1.00000000000000E+0000; -only_co

SOLUTION 45; -water 2.15609030630958E-0001

$\mathrm{pH} 7.09$; \#pe 14 O2 (g) -2

$\mathrm{Na} \mathrm{239; \quad K} 1.54 ;$

Alkalinity 2.5 ; $S(6) 12.6$;

Mg 17.2;

Ca 25.9;

Sr 0.500

E-0004; $472.54517390654883 \mathrm{E}-0002$

SURFACE 46; -equil 46; Su 8.13739290869853E-0001 6.78116075724602E+0005

-donnan $3.74999999999975 \mathrm{E}-0010 \mathrm{v} 1.00000000000000 \mathrm{E}+0000$; -only_co

SOLUTION 46; -water $2.54293528396829 \mathrm{E}-0001$

pH 7.09; \#pe 14 O2 (g) -2

$\mathrm{Na} \mathrm{239; \quad K} 1.54 ;$

$\operatorname{Mg} 17.2$;

Ca 25.9;

$\operatorname{Sr} 0.500$

Alkalinity 2.5 ; $\mathrm{S}(6) 12.6$

MIX 47; $873.23121462957232 \mathrm{E}-0004 ; 482.90499079628717 \mathrm{E}-0002$;

SURFACE 47; -equil 47; Su 9.37529683721368E-0001 7.81274736433983E+0005 1

-donnan $3.74999999999975 \mathrm{E}-0010 \mathrm{~V} \quad 1.00000000000000 \mathrm{E}+0000$; -only_co

SOLUTION 47 ; -water $2.92978026162928 \mathrm{E}-0001$

pH 7.09; \#pe 14 O2 (g) -2

$\mathrm{Na} \mathrm{239; \quad K} \mathrm{1.54;} \quad$ Mg 17.2; $\quad$ Ca 25.9; $\quad$ Sr 0.500

Alkalinity $2.5 ; \mathrm{S}(6) 12.6 ; \quad$ Cl 304 charge

MIX 48; 88 2.85433188980733E-0004; $493.26480845735091 \mathrm{E}-0002$;

SURFACE 48; -equil 48; Su 1.06132007657288E+0000 8.84433397144318E+0005 1

-donnan 3.74999999999975E-0010 v $1.00000000000000 \mathrm{E}+0000$; -only_co

SOLUTION 48; -water $3.31662523929026 \mathrm{E}-0001$

pH 7.09; \#pe 14 O2 (g) -2

$\mathrm{Na} \mathrm{239; \quad K} 1.54 ;$

$\operatorname{Mg} 17.2$;

Ca 25.9;

$\operatorname{Sr} 0.500$

Alkalinity 2.5; S(6) 12.6; Cl 304 charge

MIX 49; 89 2.55618333846641E-0004; 50 3.62462457576385E-0002;

SURFACE 49; -equil 49; Su 1.18511046942440E+0000 9.87592057853699E+0005 1

-donnan 3.74999999999975E-0010 v 1.00000000000000E+0000; -only_co

SOLUTION 49; -water $3.70347021695125 \mathrm{E}-0001$

$\mathrm{pH} 7.09 ;$ \#pe $14 \mathrm{O} 2(\mathrm{~g})-2$

$\mathrm{Na} \mathrm{239; \quad K} \mathrm{1.54; \quad Mg} \mathrm{17.2;} \quad$ Ca 25.9; $\quad$ Sr 0.500

Alkalinity 2.5; S(6) 12.6; Cl 304 charge

MIX 50; 90 2.31443023088929E-0004; 51 3.98444146550219E-0002;

SURFACE 50; -equil 50; Su 1.30890086227446E+0000 1.09075071856117E+0006 1

-donnan 3.74999999999975E-0010 v 1.00000000000000E+0000; -only_co

SOLUTION 50; -water $4.09031519461223 \mathrm{E}-0001$

pH 7.09; \#pe 14 O2 (g) -2

$\mathrm{Na} \mathrm{239; \quad K} 1.54 ;$

Alkalinity $2.5 ; \mathrm{S}(6) 12.6$;

$\operatorname{Mg} 17.2$;

Ca 25.9 .

$\operatorname{Sr} 0.500$

SURFACE 51; -equil 51; Su 1.43269125512597E+0000 1.19390937927246E+0006 1

-donnan 3.74999999999975E-0010 v $1.00000000000000 \mathrm{E}+0000$; -only_co

SOLUTION 51; -water $4.47716017226412 \mathrm{E}-0001$

pH 7.09; \#pe 1402 (g) -2

$\mathrm{Na} \mathrm{239; \quad K} 1.54 ;$

$\operatorname{Mg} 17.2$;

Ca 25.9;

Sr 0.500

Alkalinity $2.5 ; \mathrm{S}(6) 12.6 ; \quad \mathrm{Cl} 304$ charge

MIX 52; $921.94628681947151 \mathrm{E}-0004 ; 534.70407524497887 \mathrm{E}-0002$;

SURFACE 52; -equil 52; Su 1.55648164797749E+0000 1.29706803998184E+0006 1

-donnan $3.74999999999975 \mathrm{E}-0010 \mathrm{v} 1.00000000000000 \mathrm{E}+0000$; -only_co

SOLUTION 52; -water $4.86400514992965 \mathrm{E}-0001$

$\mathrm{pH} 7.09 ;$ \#pe $14 \mathrm{O} 2(\mathrm{~g})-2$

Na 239; K 1.54; Mg 17.2; Ca 25.9; $\quad$ Sr 0.500

Alkalinity $2.5 ; \mathrm{S}(6)$ 12.6; Cl 304 charge

MIX 53; $931.80289836276515 \mathrm{E}-0004 ; 545.06389213471721 \mathrm{E}-0002$;

SURFACE 53; -equil 53; Su 1.68027204083046E+0000 1.40022670069122E+0006 1

-donnan 3.74999999999975E-0010 v 1.00000000000000E+0000; -only_co

SOLUTION 53; -water $5.25085012759519 \mathrm{E}-0001$

$\mathrm{pH} 7.09 ;$ \#pe $14 \mathrm{O} 2(\mathrm{~g})-2$

$\mathrm{Na} \mathrm{239; \quad K} 1.54$;

Alkalinity $2.5 ; \mathrm{S}(6) 12.6$;

$\operatorname{Mg} 17.2$;

Ca 25.9;

$\operatorname{Sr} 0.500$

IX 54; $941.67918784334731 \mathrm{E}-0004 ; 555.42371158720698 \mathrm{E}-0002$;

SURFACE 54; -equil 54; Su 1.80406243368052E+0000 1.50338536140060E+0006 1

-donnan $3.74999999999975 \mathrm{E}-0010$ v $1.00000000000000 \mathrm{E}+0000$; -only_co

SOLUTION 54; -water $5.63769510525162 \mathrm{E}-0001$

$\mathrm{pH} 7.09 ;$ \#pe $1402(\mathrm{~g})-2$

Na $239 ;$

$\operatorname{Mg} 17.2$;

Ca 25.9;

Sr 0.500 
Alkalinity 2.5; S(6) 12.6; Cl 304 charge

MIX 55; $951.57136448894235 \mathrm{E}-0004 ; 565.78352591419389 \mathrm{E}-0002$;

SURFACE 55; -equil 55; Su 1.92785282653349E+0000 1.60654402211189E+0006 1

-donnan 3.74999999999975E-0010 v 1.00000000000000E+0000; -only_co

SOLUTION 55; -water $6.02454008291716 \mathrm{E}-0001$

$\mathrm{pH} \mathrm{7.09;} \mathrm{\# pe} 14 \mathrm{O} 2(\mathrm{~g})-2$

$\mathrm{Na} \mathrm{239; \quad K} \mathrm{1.54;}$

Alkalinity $2.5 ; \mathrm{S}(6) 12.6$;

Mg 17.2;

Ca 25.9;

Sr 0.500

( 57 . $14334622682691 \mathrm{E}-0002$

SURFACE 56; -equil 56; Su 2.05164321938355E+0000 1.70970268281937E+0006 1

-donnan 3.74999999999975E-0010 v 1.00000000000000E+0000; -only_co

SOLUTION 56; -water $6.41138506057359 \mathrm{E}-0001$

pH 7.09; \#pe 14 O2 (g) -2
$\mathrm{Na} \mathrm{239;}$
K 1.54 ;
Mg 17.2;
Ca 25.9;
Sr 0.500

Alkalinity 2.5; S(6) 12.6; Cl 304 charge

MIX 57; $971.39253148892315 \mathrm{E}-0004 ; 586.50315607028915 \mathrm{E}-0002$;

SURFACE 57; -equil 57; Su 2.17543361223361E+0000 1.81286134352875E+0006 1

-donnan $3.74999999999975 \mathrm{E}-0010 \mathrm{v} 1.00000000000000 \mathrm{E}+0000$; -only_co

SOLUTION 57; -water $6.79823003823003 \mathrm{E}-0001$

$\mathrm{pH} 7.09$; \#pe $1402(\mathrm{~g})-2$
$\mathrm{Na} \mathrm{239;}$
$\mathrm{K} 1.54$;
$\operatorname{Mg} 17.2$;
Ca 25.9;
Sr 0.500

Alkalinity $2.5 ; \mathrm{S}(6)$ 12.6; Cl 304 charge

MIX 58; $981.31755735669614 \mathrm{E}-0004 ; 596.86298040726570 \mathrm{E}-0002$;

SURFACE 58; -equil 58; Su 2.29922400508658E+0000 1.91602000423813E+0006 1

-donnan $3.74999999999975 \mathrm{E}-0010 \mathrm{~V} 1.00000000000000 \mathrm{E}+0000$; -only_co

SOLUTION 58; -water $7.18507501589556 \mathrm{E}-0001$

pH 7.09; \#pe 14 O2 (g) -2
$\mathrm{Na} \mathrm{239;}$
$\mathrm{K} 1.54$;
$\operatorname{Mg} 17.2$;
Ca 25.9 ;
$\operatorname{Sr} 0.500$
Alkalinity $2.5 ; \mathrm{S}(6) \quad 12.6 ; \quad$ Cl 304 charge

MIX 59; $991.25024427756415 \mathrm{E}-0004 ; 607.22278944880372 \mathrm{E}-0002$;

SURFACE 59; -equil 59; Su 2.42301439793664E+0000 2.01917866494751E+0006 1

-donnan 3.74999999999975E-0010 v $1.00000000000000 \mathrm{E}+0000$; -only_co

SOLUTION 59; -water 7.57191999355200E-0001

$\mathrm{pH} 7.09 ;$ \#pe 14 O2 (g) -2
$\mathrm{Na} 239 ; \quad \mathrm{K} 1.54 ;$

Alkalinity 2.5; S(6) 12.6 ;

$\operatorname{Mg} 17.2$;

Ca 25.9;

Sr 0.500

MIX 60; $1001.18947459880658 \mathrm{E}-0004 ; 617.58261458770448 \mathrm{E}-0002$;

SURFACE 60; -equil 60; Su 2.54680479078961E+0000 2.12233732565689E+0006 1

-donnan $3.74999999999975 \mathrm{E}-0010 \mathrm{~V} 1.00000000000000 \mathrm{E}+0000$; -only_co

SOLUTION 60; -water 7.95876497122663E-0001

$\mathrm{pH} 7.09$; \#pe $14 \mathrm{O} 2(\mathrm{~g})-2$
$\mathrm{Na} 239$;
$\mathrm{K} 1.54 ;$
$\operatorname{Mg} 17.2$;
Ca 25.9;
Sr 0.500

Alkalinity $2.5 ; \mathrm{S}(6)$ 12.6; Cl 304 charge

MIX 61; $1011.13433878512303 \mathrm{E}-0004 ; 62$ 7.94243167790682E-0002;

SURFACE 61; -equil 61; Su 2.67059518363967E+0000 2.22549598636627E+0006 1

-donnan $3.74999999999975 \mathrm{E}-0010 \mathrm{~V} 1.00000000000000 \mathrm{E}+0000$; -only_co

SOLUTION 61; -water $8.34560994887397 \mathrm{E}-0001$

pH 7.09; \#pe 14 O2 (g) -2

$\mathrm{Na} \mathrm{239; \quad K} 1.54 ;$

Alkalinity $2.5 ; \mathrm{S}(6) 12.6$;

$\operatorname{Mg} 17.2$;

Ca 25.9;

Sr 0.500

MIX 62; $1021.08408802396198 \mathrm{E}-0004 ; 63$ 8.30223951656990E-0002;

SURFACE 62; -equil 62; Su 2.79438557648973E+0000 2.32865464707565E+0006 1

-donnan $3.74999999999975 \mathrm{E}-0010 \mathrm{~V} 1.00000000000000 \mathrm{E}+0000$; -only_co

SOLUTION 62; -water 8.73245492653041E-0001

$\mathrm{pH} 7.09$; \#pe $1402(\mathrm{~g})-2$

Na 239; K $1.54 ;$

$\operatorname{Mg} 17.2$;

Ca 25.9;

Sr 0.500

Alkalinity 2.5; S(6) 12.6; Cl 304 charge

MIX 63; $1031.03810041757946 \mathrm{E}-0004 ; 641.55015703827985 \mathrm{E}-0001$;

SURFACE 63; -equil 63; Su 2.91817596934270E+0000 2.43181330778503E+0006 1

-donnan 3.74999999999975E-0010 v 1.00000000000000E+0000; -only_co

SOLUTION 63; -water 9.11929990419594E-0001

pH 7.09; \#pe 14 O2 (g) -2
$\mathrm{Na} 239$;
$\mathrm{K} 1.54$;
$\operatorname{Mg} 17.2$;
Ca 25.9;
Sr 0.500

Alkalinity $2.5 ; \mathrm{S}(6) 12.6 ; \quad$ Cl 304 charge

MIX 64; $1042.56849692903671 \mathrm{E}-0004 ; 652.32690840093255 \mathrm{E}-0001$;

SURFACE 64; -equil 64; Su 3.04196636219276E+0000 2.53497196849442E+0006 1

-donnan 3.74999999999975E-0010 v 1.00000000000000E+0000; -only_co

SOLUTION 64 ; -water $9.50614488185238 \mathrm{E}-0001$

pH 7.09; \#pe 14 O2 (g) -2

Na 239; K $1.54 ;$

Alkalinity $2.5 ; \mathrm{S}(6) 12.6$;

Mg 17.2;

Ca 25.9;

Sr 0.500

SURFACE 65; -equil 65; Su 3.16575675504573E+0000 2.63813062920380E+0006

-donnan $3.74999999999975 \mathrm{E}-0010 \mathrm{~V} 1.00000000000000 \mathrm{E}+0000$; -only_co

SOLUTION 65; -water $9.89298985951791 \mathrm{E}-0001$

$\mathrm{pH} 7.09 ;$ \#pe $14 \mathrm{O} 2(\mathrm{~g})-2$
Na 239;
K 1.54 ;
$\operatorname{Mg} 17.2$;
Ca 25.9;
Sr 0.500 
Alkalinity 2.5; S(6) 12.6 ;

Cl 304 charge

MIX 66; $1069.20904800961964 \mathrm{E}-0005 ; 67$ 9.74150627361041E-0002;

SURFACE 66; -equil 66; Su 3.28954714789870E+0000 2.74128928991699E+0006 1

-donnan 3.74999999999975E-0010 V 1.00000000000000E+0000; -only_co

SOLUTION 66; -water $1.02798348371834 \mathrm{E}+0000$

pH 7.09; \#pe 14 O2 (g) -2

$\mathrm{Na} 239 ; \quad \mathrm{K} \mathrm{1.54;} \quad$ Mg 17.2; $\quad$ Ca 25.9; $\quad$ Sr 0.500

Alkalinity 2.5; S(6) 12.6; Cl 304 charge

MIX 67; $1078.87506627452517 \mathrm{E}-0005 ; 681.01013342192346 \mathrm{E}-0001$;

SURFACE 67; -equil 67; Su 3.41333754074876E+0000 2.84444795062256E+0006 1

-donnan 3.74999999999975E-0010 v 1.00000000000000E+0000; -only_co

SOLUTION 67; -water $1.06666798148399 \mathrm{E}+0000$

pH 7.09; \#pe 14 O2(g) -2

$\mathrm{Na} \mathrm{239; \quad K} 1.54 ;$

$\operatorname{Mg} 17.2$;

Ca 25.9;

$\operatorname{Sr} 0.500$

Alkalinity $2.5 ; \mathrm{S}(6) \quad 12.6 ; \quad$ Cl 304 charge

MIX 68; 108 8.56446193249205E-0005; $691.04611396521136 \mathrm{E}-0001$;

SURFACE 68; -equil 68; Su 3.53712793359882E+0000 2.94760661133194E+0006

-donnan $3.74999999999975 \mathrm{E}-0010 \mathrm{v} 1.00000000000000 \mathrm{E}+0000$; -only_co

SOLUTION 68; -water $1.10535247924963 \mathrm{E}+0000$

pH 7.09; \#pe 14 O2 (g) -2

$\mathrm{K} 1.54$;

$\operatorname{Mg} 17.2$;

Ca 25.9;

Sr 0.500

Alkalinity 2.5; S(6) 12.6; Cl 304 charge

MIX 69; $1098.27486246398834 \mathrm{E}-0005 ; 701.08209683996506 \mathrm{E}-0001$;

SURFACE 69; -equil 69; Su 3.66091832644888E+0000 3.05076527204132E+0006 1

-donnan $3.74999999999975 \mathrm{E}-0010 \mathrm{~V} 1.00000000000000 \mathrm{E}+0000$; -only_co

SOLUTION 69; -water $1.14403697701528 \mathrm{E}+0000$

$\mathrm{pH} 7.09$; \#pe $14 \mathrm{O} 2(\mathrm{~g})-2$

Na 239; $\quad \mathrm{K} \mathrm{1.54;} \quad$ Mg 17.2; $\quad$ Ca 25.9; $\quad$ Sr 0.500

Alkalinity $2.5 ; \mathrm{S}(6) 12.6 ; \quad$ Cl 304 charge

MIX 70; $1108.00420812663738 \mathrm{E}-0005 ; 71$ 1.11807730306396E-0001;

SURFACE 70; -equil 70; Su 3.78470871929894E+0000 3.15392393275070E+0006 1

-donnan 3.74999999999975E-0010 v $1.00000000000000 \mathrm{E}+0000$; -only_co

SOLUTION 70; -water $1.18272147478092 \mathrm{E}+0000$

pH 7.09; \#pe 14 O2(g) -2

$\mathrm{Na} \mathrm{239; \quad K} 1.54 ;$

$\operatorname{Mg} 17.2$;

Ca 25.9;

$\operatorname{Sr} 0.500$

Alkalinity 2.5; S(6) 12.6; Cl 304 charge

MIX 71; $1117.75069786463689 \mathrm{E}-0005 ; 72$ 1.15406025801121E-0001;

SURFACE 71; -equil 71; Su 3.90849911214900E+0000 3.25708259345627E+0006

-donnan 3.74999999999975E-0010 v 1.00000000000000E+0000; -only_co

SOLUTION 71; -water $1.22140597254656 \mathrm{E}+0000$

$\mathrm{pH} 7.09 ;$ \#pe $14 \mathrm{O} 2(\mathrm{~g})-2$

$\mathrm{Na} \mathrm{239; \quad K} \mathrm{1.54;} \quad$ Mg 17.2; $\quad$ Ca 25.9; $\quad$ Sr 0.500

Alkalinity 2.5; S(6) 12.6; Cl 304 charge

MIX 72; $1127.51275386042138 \mathrm{E}-0005 ; 731.19004196703031 \mathrm{E}-0001$;

SURFACE 72; -equil 72; Su 4.03228950499906E+0000 3.36024125416565E+0006 1

-donnan 3.74999999999975E-0010 v 1.00000000000000E+0000; -only_co

SOLUTION 72; -water $1.26009047031221 \mathrm{E}+0000$

pH 7.09; \#pe $1402(\mathrm{~g})-2$

$\mathrm{Na} \mathrm{239; \quad K} 1.54 ;$

Alkalinity $2.5 ; \mathrm{S}(6) 12.6$;

$\operatorname{Mg} 17.2$;

Ca 25.9;

Sr 0.500

IX 73; $1137.28898379970033 \mathrm{E}-0005 ; 741.22602094363174 \mathrm{E}-0001$;

SURFACE 73; -equil 73; Su 4.15607989785494E+0000 3.46339991487885E+0006 1

-donnan 3.74999999999975E-0010 v $1.00000000000000 \mathrm{E}+0000$; -only_co

SOLUTION 73; -water $1.29877496807967 \mathrm{E}+0000$

$\mathrm{pH} 7.09 ;$ \#pe $14 \mathrm{O} 2(\mathrm{~g})-2$

$\mathrm{Na} \mathrm{239; \quad K} 1.54$;

$\operatorname{Mg} 17.2$;

Ca 25.9;

$\operatorname{Sr} 0.500$

Alkalinity 2.5; S(6) 12.6; Cl 304 charge

MIX 74; $1147.07815732447159 \mathrm{E}-0005 ; 751.26200538507646 \mathrm{E}-0001$;

SURFACE 74; -equil 74; Su 4.27987029070500E+0000 3.56655857558823E+0006

-donnan 3.74999999999975E-0010 V 1.00000000000000E+0000; -only_co

SOLUTION 74; -water $1.33745946584531 \mathrm{E}+0000$

$\mathrm{pH} 7.09$; \#pe $14 \mathrm{O} 2(\mathrm{~g})-2$

$\mathrm{Na} \mathrm{239;} \quad \mathrm{K} \mathrm{1.54;} \quad$ Mg 17.2; $\quad$ Ca 25.9; $\quad$ Sr 0.500

Alkalinity 2.5; S(6) $12.6 ; \quad$ Cl 304 charge

MIX 75; $1156.87918483918359 \mathrm{E}-0005 ; 761.29798709409897 \mathrm{E}-0001$;

SURFACE 75; -equil 75; Su 4.40366068355506E+0000 3.66971723629379E+0006 1

-donnan 3.74999999999975E-0010 V 1.00000000000000E+0000; -only_co

SOLUTION 75; -water $1.37614396361096 \mathrm{E}+0000$

$\mathrm{pH} 7.09 ;$ \#pe $14 \mathrm{O} 2(\mathrm{~g})-2$

$\mathrm{Na} \mathrm{239; \quad K} \mathrm{1.54;}$

Alkalinity $2.5 ; \mathrm{S}(6) 12.6$;

Mg 17.2;

Ca 25.9;

$\operatorname{Sr} 0.500$

SURFACE 76; -equil 76; Su 4.52745107641094E+0000 3.77287589700699E+0006

-donnan $3.74999999999975 \mathrm{E}-0010 \mathrm{~V} \quad 1.00000000000000 \mathrm{E}+0000$; -only_co

SOLUTION 76; -water 1.41482846137842E+0000

$\mathrm{pH} 7.09 ;$ \#pe $1402(\mathrm{~g})-2$

$\operatorname{Mg} 17.2$;

Ca 25.9;

Sr 0.500 
Alkalinity 2.5; S(6) 12.6; Cl 304 charge

MIX 77; $1176.51301356340284 \mathrm{E}-0005 ; 781.36995180677104 \mathrm{E}-0001$;

SURFACE 77; -equil 77; Su 4.65124146925518E+0000 3.87603455771255E+0006 1

-donnan $3.74999999999975 \mathrm{E}-0010 \mathrm{v} 1.00000000000000 \mathrm{E}+0000$; -only_co

SOLUTION 77; -water $1.45351295914224 \mathrm{E}+0000$

pH 7.09; \#pe 14 O2 (g) -2

$\mathrm{Na} 239 ; \quad \mathrm{K} \mathrm{1.54;} \quad$ Mg 17.2; $\quad$ Ca 25.9; $\quad$ Sr 0.500

Alkalinity 2.5; S(6) 12.6; Cl 304 charge

MIX 78; 118 6.34416692922635E-0005; 79 1.40592908778217E-0001;

SURFACE 78; -equil 78; Su 4.77503186211106E+0000 3.97919321842575E+0006 1

-donnan 3.74999999999975E-0010 v 1.00000000000000E+0000; -only_co

SOLUTION 78; -water $1.49219745690971 \mathrm{E}+0000$

pH 7.09; \#pe 14 O2 (g) -2

Na 239; $\quad$ K 1.54; $\quad$ Mg 17.2; $\quad$ Ca 25.9;

Alkalinity 2.5 ; S(6) 12.6; Cl 304 charge

MIX 79; $1196.18385283742029 \mathrm{E}-0005 ; 801.44191393018446 \mathrm{E}-0001$;

SURFACE 79; -equil 79; Su 4.89882225496112E+0000 4.08235187913513E+0006 1

-donnan $3.74999999999975 \mathrm{E}-0010 \mathrm{v} 1.00000000000000 \mathrm{E}+0000$; -only_co

SOLUTION 79; -water $1.53088195467535 \mathrm{E}+0000$

$\mathrm{pH} 7.09$; \#pe $14 \mathrm{O} 2(\mathrm{~g})-2$
$\mathrm{Na} \mathrm{239;}$
$\mathrm{K} 1.54$;
$\operatorname{Mg} 17.2$;
Ca 25.9;
Sr 0.500

Alkalinity $2.5 ; \mathrm{S}(6)$ 12.6; Cl 304 charge

MIX 80; $1206.03144190185922 \mathrm{E}-0005$; 81 1.47789563920696E-0001;

SURFACE 80; -equil 80; Su 5.02261264781700E+0000 4.18551053984833E+0006 1

-donnan $3.74999999999975 \mathrm{E}-0010 \mathrm{v} 1.00000000000000 \mathrm{E}+0000$; -only_co

SOLUTION 80 ; -water $1.56956645244281 \mathrm{E}+0000$

$\mathrm{pH} 7.09 ;$ \#pe 14 O2 (g) -2

$\mathrm{Na} \mathrm{239; \quad K} 1.54$;

Alkalinity $2.5 ; \mathrm{S}(6) 12.6$;

$\operatorname{Mg} 17.2$;

Ca 25.9;

Sr 0.500

MIX 81; $1215.88636307686130 \mathrm{E}-0005 ; 821.51387734822720 \mathrm{E}-0001$;

SURFACE 81; -equil 81; Su 5.14640304066124E+0000 4.28866920055389E+0006 1

-donnan 3.74999999999975E-0010 V $1.00000000000000 \mathrm{E}+0000$; -only_co

SOLUTION 81; -water $1.60825095020482 \mathrm{E}+0000$

$\mathrm{pH} 7.09 ;$ \#pe $14 \mathrm{O} 2(\mathrm{~g})-2$
$\mathrm{Na} \mathrm{239;}$
$\mathrm{K} 1.54$;
$\operatorname{Mg} 17.2$;
Ca 25.9;
Sr 0.500

Alkalinity 2.5 ; S(6) $12.6 ; \quad$ Cl 304 charge

MIX 82; $1225.74810001809922 \mathrm{E}-0005 ; 831.54985560310251 \mathrm{E}-0001$;

SURFACE 82; -equil 82; Su 5.27019343351712E+0000 4.39182786126709E+0006 1

-donnan $3.74999999999975 \mathrm{E}-0010 \mathrm{~V} \quad 1.00000000000000 \mathrm{E}+0000$; -only_co

SOLUTION 82; -water $1.64693544797228 \mathrm{E}+0000$

$\mathrm{pH} \mathrm{7.09;} \mathrm{\# pe} 1402(\mathrm{~g})-2$
$\mathrm{Na} \mathrm{239;}$
K 1.54 ;
Mg 17.2;
Ca 25.9;
Sr 0.500
Alkalinity $2.5 ; \mathrm{S}(6)$ 12.6; Cl 304 charge

MIX 83; $1235.61618220086046 \mathrm{E}-0005$;

SURFACE 83; -equil 83; Su 5.39398382636718E+0000 4.49498652197266E+0006 1

-donnan $3.74999999999975 \mathrm{E}-0010 \mathrm{~V} 1.00000000000000 \mathrm{E}+0000$; -only_co

SOLUTION 83; -water $1.68561994573975 \mathrm{E}+0000$

pH 7.09; \#pe 14 O2 (g) -2
$\mathrm{Na} 239$
$\mathrm{K} 1.54$;
Mg 17.2;
Ca 25.9 .
Sr 0.500
Alkalinity $2.5 ; \mathrm{S}(6) \quad 12.6 ; \quad$ Cl 304 charge

MIX 84; 85 5.41510049746421E-0002.

SURFACE 84; -equil 84; Su 5.66158505167550E-0001 4.71798754306316E+0005 1

-donnan $3.74999999999975 \mathrm{E}-0010 \mathrm{~V} 1.00000000000000 \mathrm{E}+0000$; -only_co

SOLUTION 84 ; -water $1.76924532864859 \mathrm{E}-0001$
pH 7.09; \#pe 14 O2 (g) -2
$\mathrm{Na} \mathrm{239;}$
$\mathrm{K} 1.54$
$\operatorname{Mg} 17.2$;
Ca 25.9;
Sr 0.500

Alkalinity 2.5 ; S(6) 12.6; Cl 304 charge

MIX 85; $864.49789503542775 \mathrm{E}-0002$;

SURFACE 85; -equil 85; Su 6.89948898019065E-0001 5.74957415016174E+0005 1

-donnan 3.74999999999975E-0010 v 1.00000000000000E+0000; -only_co

SOLUTION 85; -water 2.15609030630958E-0001

$\mathrm{pH} 7.09 ;$ \#pe $14 \mathrm{O} 2(\mathrm{~g})-2$
$\mathrm{Na} \mathrm{239;}$
K 1.54 ;
$\operatorname{Mg} 17.2$;
Ca 25.9;
Sr 0.500
Alkalinity $2.5 ; \mathrm{S}(6)$ 12.6; Cl 304 charge

MIX 86; $872.92718294341228 \mathrm{E}-0002$;

SURFACE 86; -equil 86; Su 8.13739290869853E-0001 6.78116075724602E+0005 1

-donnan $3.74999999999975 \mathrm{E}-0010 \mathrm{~V} 1.00000000000000 \mathrm{E}+0000$; -only_co

SOLUTION 86 ; -water $2.54293528396829 \mathrm{E}-0001$

pH 7.09; \#pe 14 O2 (g) -2

$\mathrm{Na} \mathrm{239; \quad K} 1.54 ;$

Alkalinity $2.5 ; \mathrm{S}(6) 12.6$;

MIX 87; $883.34100761278933 \mathrm{E}-0002 ;$

$\operatorname{Mg} 17.2 ; \quad$ Ca $25.9 ;$

$\operatorname{Sr} 0.500$

SURFACE 87; -equil 87; Su 9.37529683721368E-0001 7.81274736433983E+0005 1

-donnan $3.74999999999975 \mathrm{E}-0010 \mathrm{~V} \quad 1.00000000000000 \mathrm{E}+0000$; -only_co

SOLUTION 87 ; -water 2.92978026162928E-0001

$\mathrm{pH} 7.09 ;$ \#pe $14 \mathrm{O} 2(\mathrm{~g})-2$
Na 239;
K 1.54;
$\operatorname{Mg} 17.2$;
Ca 25.9;
Sr 0.500 
Alkalinity 2.5; S(6) 12.6; Cl 304 charge

MIX $88 ; 893.75483047828311 \mathrm{E}-0002$;

SURFACE 88; -equil 88; Su 1.06132007657288E+0000 8.84433397144318E+0005 1

-donnan $3.74999999999975 \mathrm{E}-0010 \mathrm{v} 1.00000000000000 \mathrm{E}+0000$; -only_co

SOLUTION 88; -water $3.31662523929026 \mathrm{E}-0001$

$\mathrm{pH} 7.09 ;$ \#pe $1402(\mathrm{~g})-2$

$\begin{array}{lllll}\text { Na 239; } & \mathrm{K} 1.54 ; & \text { Mg 17.2; } & \text { Ca 25.9; } & \text { Sr } 0.500 \\ \text { Alkalinity 2.5; S (6) 12.6; } & \text { Cl 304 charge } & \end{array}$

MIX 89; $904.16865289782891 \mathrm{E}-0002$;

SURFACE 89; -equil 89; Su 1.18511046942440E+0000 9.87592057853699E+0005 1

-donnan 3.74999999999975E-0010 v 1.00000000000000E+0000; -only_co

SOLUTION 89; -water $3.70347021695125 \mathrm{E}-0001$

$\mathrm{pH} 7.09$; \#pe $14 \mathrm{O} 2(\mathrm{~g})-2$

Na 239; K 1.54; $\quad$ Mg 17.2; $\quad$ Ca 25.9;

Alkalinity 2.5 ; S(6) 12.6; Cl 304 charge

MIX 90; $914.58247236734906 \mathrm{E}-0002$;

SURFACE 90; -equil 90; Su 1.30890086227446E+00001.09075071856117E+0006 1

-donnan $3.74999999999975 \mathrm{E}-0010 \mathrm{~V} 1.00000000000000 \mathrm{E}+0000$; -only_co

SOLUTION 90; -water $4.09031519461223 \mathrm{E}-0001$

$\mathrm{pH} 7.09$; \#pe $14 \mathrm{O} 2(\mathrm{~g})-2$
$\mathrm{Na} \mathrm{239;}$
$\mathrm{K} 1.54$;
Mg 17.2;
Ca 25.9;
Sr 0.500

Alkalinity 2.5; S(6) 12.6 ;

MIX 91; 92 4.99629788617426E-0002;

SURFACE 91; -equil 91; Su 1.43269125512597E+0000 1.19390937927246E+0006 1

-donnan $3.74999999999975 \mathrm{E}-0010 \mathrm{~V} 1.00000000000000 \mathrm{E}+0000$; -only_co

SOLUTION 91; -water $4.47716017226412 \mathrm{E}-0001$

$\mathrm{pH} 7.09 ;$ \#pe 14 O2 (g) -2

$\mathrm{Na} \mathrm{239; \quad K} 1.54 ;$

Alkalinity $2.5 ; \mathrm{S}(6) 12.6$;

MIX 92; $935.41012114667865 \mathrm{E}-0002$

SURFACE 92; -equil 92; Su 1.55648164797749E+0000 1.29706803998184E+0006 1

-donnan 3.74999999999975E-0010 V 1.00000000000000E+0000; -only_co

SOLUTION 92; -water $4.86400514992965 \mathrm{E}-0001$

$\mathrm{pH} 7.09 ;$ \#pe $14 \mathrm{O} 2(\mathrm{~g})-2$
$\mathrm{Na} \mathrm{239;}$
$\mathrm{K} 1.54$;
Mg 17.2;
Ca 25.9;
Sr 0.500

Alkalinity 2.5; S(6) 12.6; Cl 304 charge

MIX 93; 94 5.82394381377185E-0002;

SURFACE 93; -equil 93; Su 1.68027204083046E+0000 1.40022670069122E+0006 1

-donnan 3.74999999999975E-0010 v 1.00000000000000E+0000; -only_co

SOLUTION 93; -water 5.25085012759519E-0001

$\mathrm{pH} 7.09$; \#pe 14 O2 (g) -2
$\mathrm{Na} 239$;
$\mathrm{K} 1.54$;
$\operatorname{Mg} 17.2$;
Ca 25.9;
Sr 0.500
Alkalinity $2.5 ; \mathrm{S}(6) 12.6 ; \quad$ Cl 304 charge

MIX 94; $956.23776179126594 \mathrm{E}-0002$;

SURFACE 94; -equil 94; Su 1.80406243368052E+0000 1.50338536140060E+0006 1

-donnan $3.74999999999975 \mathrm{E}-0010 \mathrm{~V} 1.00000000000000 \mathrm{E}+0000$; -only_co

SOLUTION 94; -water $5.63769510525162 \mathrm{E}-0001$

pH 7.09; \#pe 14 O2 (g) -2
Na 239;
$\mathrm{K} 1.54$;
Mg 17.2;
Ca 25.9 .
$\operatorname{Sr} 0.500$
Alkalinity 2.5; S(6) 12.6; Cl 304 charge

MIX 95; $966.65159335868566 \mathrm{E}-0002$;

SURFACE 95; -equil 95; Su 1.92785282653349E+0000 1.60654402211189E+0006 1

-donnan 3.74999999999975E-0010 v 1.00000000000000E+0000; -only_co

SOLUTION 95; -water $6.02454008291716 \mathrm{E}-0001$

$\mathrm{pH} 7.09 ;$ \#pe $14 \mathrm{O} 2(\mathrm{~g})-2$

$\mathrm{Na} \mathrm{239;} \quad \mathrm{K} 1.54 ; \quad$ Mg 17.2; $\quad$ Ca 25.9; $\quad$ Sr 0.500

Alkalinity 2.5; S(6) 12.6; Cl 304 charge

MIX 96; $977.06540650323859 \mathrm{E}-0002$;

SURFACE 96; -equil 96; Su 2.05164321938355E+0000 1.70970268281937E+0006 1

-donnan 3.74999999999975E-0010 V $1.00000000000000 \mathrm{E}+0000$; -only_co

SOLUTION 96; -water $6.41138506057359 \mathrm{E}-0001$

$\mathrm{pH} 7.09 ;$ \#pe $14 \mathrm{O} 2(\mathrm{~g})-2$
$\mathrm{Na} 239$;
K 1.54 ;
$\operatorname{Mg} 17.2$;
Ca 25.9;
Sr 0.500
Alkalinity $2.5 ; \mathrm{S}(6)$ 12.6; Cl 304 charge

MIX 97; $987.47922885922208 \mathrm{E}-0002$;

SURFACE 97; -equil 97; Su 2.17543361223361E+0000 1.81286134352875E+0006 1

-donnan $3.74999999999975 \mathrm{E}-0010 \mathrm{v} 1.00000000000000 \mathrm{E}+0000$; -only_co

SOLUTION 97; -water $6.79823003823003 \mathrm{E}-0001$

pH 7.09; \#pe 14 O2 (g) -2
Na 239;
K 1.54 ;
Mg 17.2;
Ca 25.9;
Sr 0.500
Alkalinity $2.5 ; \mathrm{S}(6) \quad 12.6 ; \quad$ Cl 304 charge

MIX 98; $997.89306214586531 \mathrm{E}-0002$;

SURFACE 98; -equil 98; Su 2.29922400508658E+0000 1.91602000423813E+0006 1

-donnan 3.74999999999975E-0010 v 1.00000000000000E+0000; -only_Co

SOLUTION 98; -water $7.18507501589556 \mathrm{E}-0001$

$\mathrm{pH} 7.09 ;$ \#pe $14 \mathrm{O} 2(\mathrm{~g})-2$
Na 239;
K 1.54;
Mg 17.2;
Ca 25.9;
Sr 0.500 


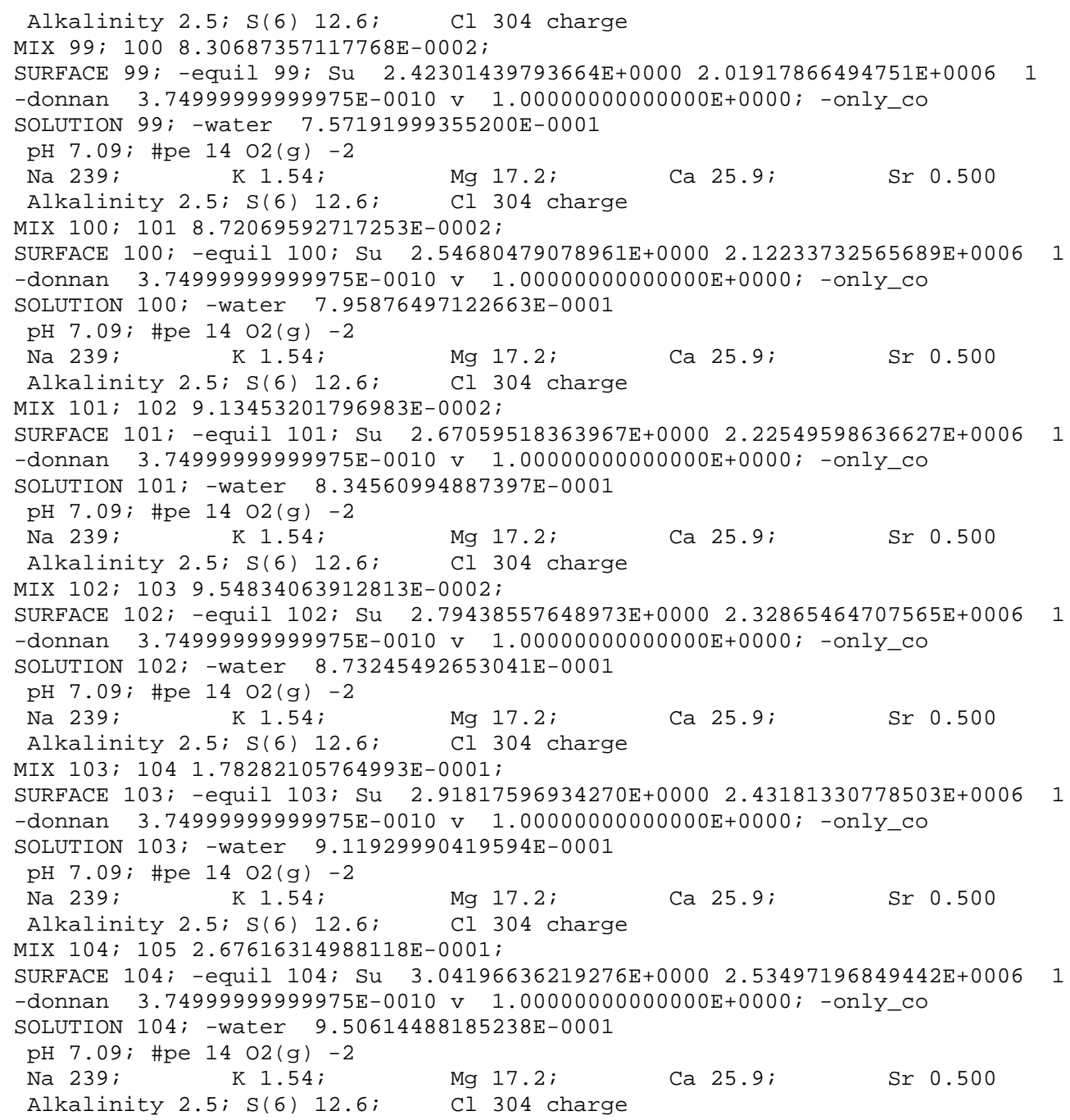




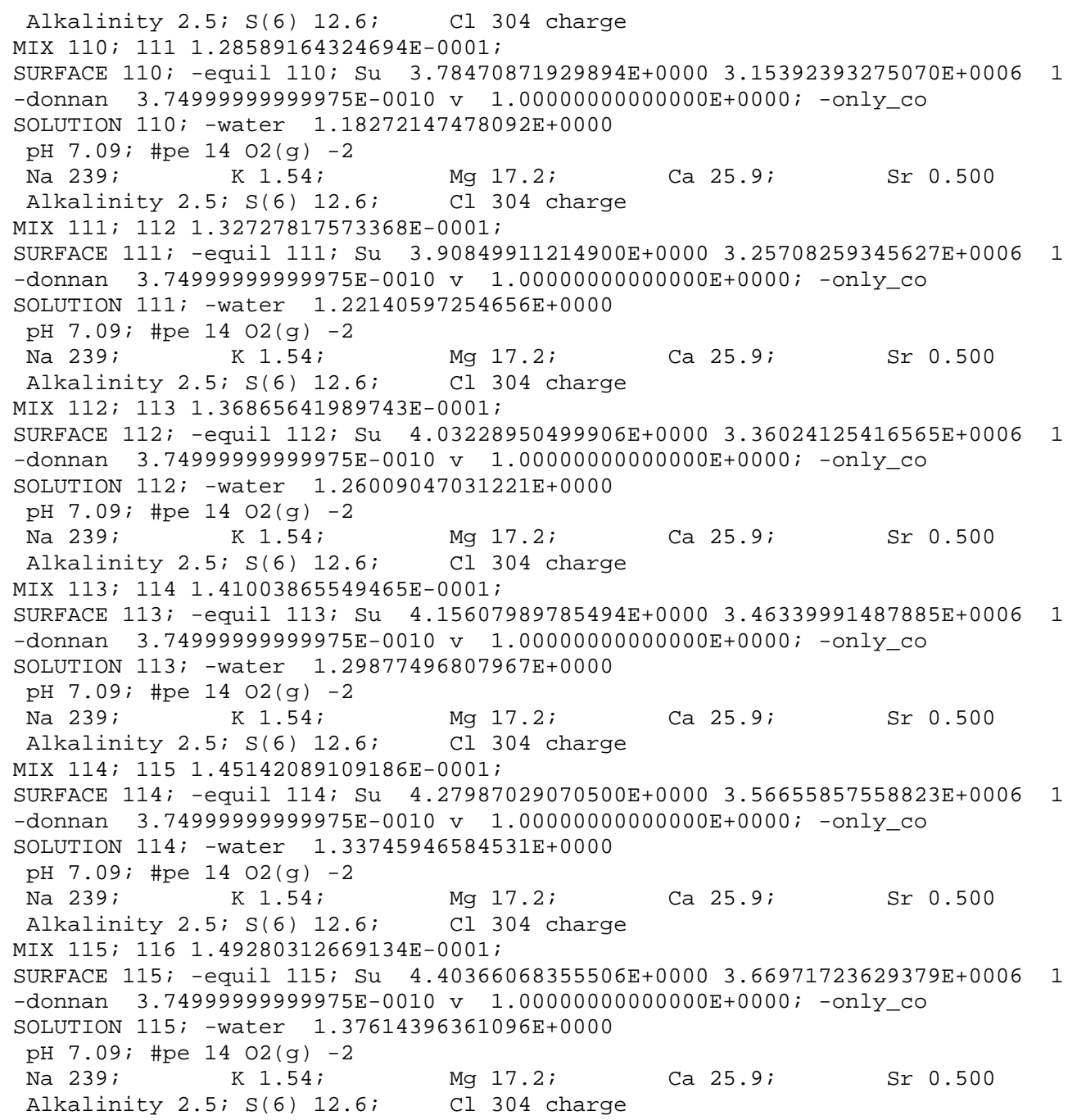




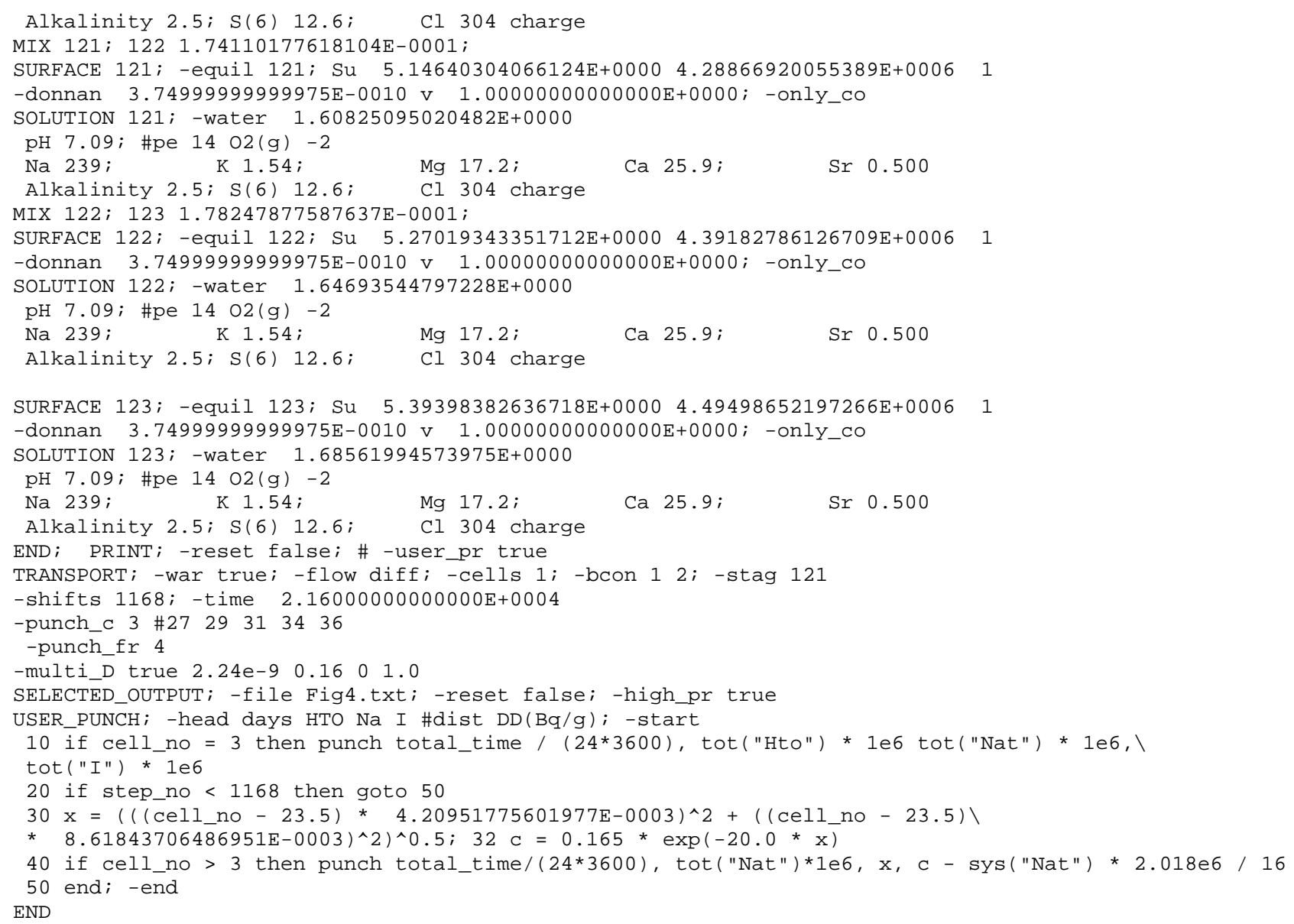

